\title{
38. EFFECT OF AXIAL MAGMA CHAMBERS BENEATH SPREADING CENTERS ON THE COMPOSITIONS OF BASALTIC ROCKS
}

\author{
James H. Natland, Scripps Institution of Oceanography, La Jolla, California
}

\begin{abstract}
Ferrobasalts are among a range of basalt types erupted over large, shallow, axial magma chambers beneath the East Pacific Rise crest near $9^{\circ} \mathrm{N}$, and the Galapagos Rift near $86^{\circ} \mathrm{W}$. Geological and geochemical evidence indicates that they evolve in small, isolated magma bodies either in conduit systems over the chambers, or in the solidifying walls of the magma chamber flanks away from the loci of fissure eruptions. The chambers act mainly as buffers in which efficient mixing ensures that a uniform average, moderately fractionated parent is supplied to the range of magma types erupted at the sea floor. Formation of ferrobasalts in isolated magma bodies prevents them from mixing directly with primitive olivine tholeiite supplied to the base of the East Pacific Rise magma chamber at $9^{\circ} \mathrm{N}$.

Rises with abundant ferrobasalts may have magma chambers with broad, flat tops over which eruptions occur in wide, probably structurally unstable rift zones. Rises without ferrobasalts may have magma chambers with tapered tops which persistently constrain eruptions to narrow fissure zones, preventing formation of isolated shallow magma bodies where ferrobasalts can evolve. Formation of a flat-topped, rather than a tapered, magma chamber may reflect a high rate of magma supply relative to spreading rate.

Steady-state compositions can be approached in magma chambers, probably approximating the least-fractionated typical lavas erupted above them. On this basis, the bulk magma composition in the chamber beneath the Galapagos Rift has become more iron-rich through time, a consequence of magma migration eastward down the rift as it shoaled to the west under the influence of the Galapagos Island hot spot.

Ferrobasalts rarely erupt at the slow-spreading Mid-Atlantic Ridge. Instead, geochemical evidence indicates that they can mix with significant proportions $(50-70 \%)$ of primitive olivine tholeite both deep in the crust prior to ascent, and at shallow levels in the crust during ascent. They are brought to the surface usually only after having been entrained in, mixed with, and diluted by primitive olivine tholeiite. Mixing evidently occurs in small magma bodies infrequently supplied with magma. Lavas of contrasting geochemistry and histories of fractionation and mixing have been supplied to the same DSDP sites. This implies that separate, unlinked reservoir-conduit systems exist, rather than the shallow, interconnected, steadystate axial magma chambers of faster spreading rises.
\end{abstract}

\section{INTRODUCTION}

A major objective of Leg 54 was to evaluate the effect of the East Pacific Rise sub-axial magma chamber (Orcutt et al., 1975, 1976; Rosendahl et al., 1976; Rosendahl, 1976; Sleep and Rosendahl, 1979) on magma compositions. We expected that the compositions of the rocks we cored would elucidate processes in the magma chamber and lead to greater understanding of the causes of petrologic diversity at both slow- and fast-spreading ridges. We did not succeed in drilling the deep hole on fast-spreading crust that we had planned. Nevertheless, our results bear on and constrain conceptions of risecrest petrogenesis.
During Leg 54, drilling for basement was undertaken in 13 holes at nine sites, all in very young crust, 0.6-4.2 m.y. old. Five of the holes were on the Galapagos Rift, four of them at one site at the Galapagos mounds geothermal field. All the other holes but one were drilled in a more or less east-west transect on the flanks of the East Pacific Rise near $9^{\circ} \mathrm{N}$ (Figure 1). The remaining hole was drilled in the Siqueiros fracture zone. Details on the site locations, ship and drilling operations, and lithologic descriptions of igneous rocks recovered at the various sites are given in the Site Reports of this volume.

Besides drilled rocks, a large number of basalts have been recovered in the vicinity of our East Pacific Rise drill sites by dredging (Batiza et al., 1977; Johnson, 


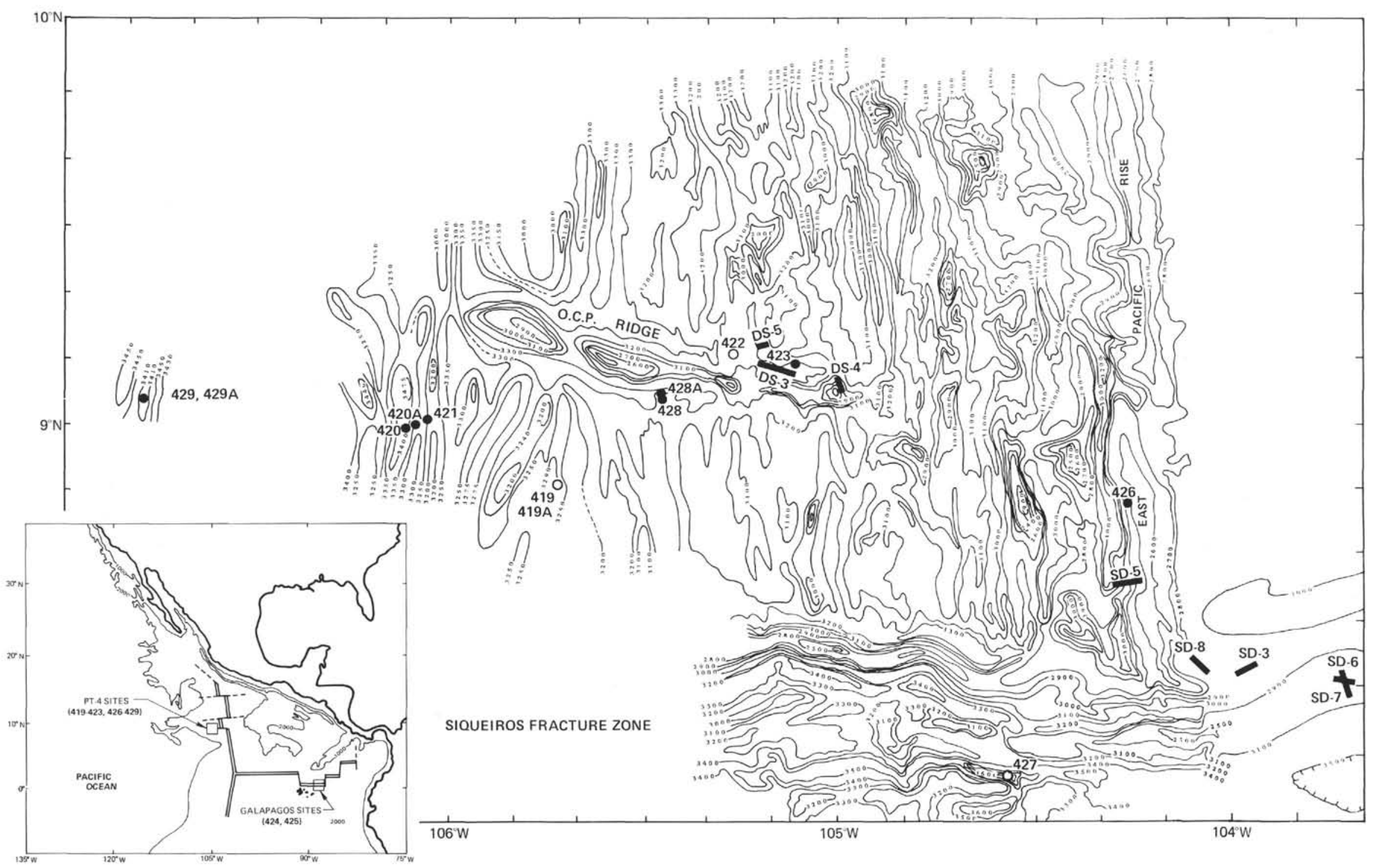

Figure 1. Location of sites drilled during Leg 54. Bathymetric chart is of PT-4 survey area, from Rosendahl and Dorman (this volume), shows location of dredge stations (Batiza et al., 1977; Johnson, 1979; Batiza and Johnson, this volume; Lonsdale and Spiess, 1979). Inset shows location of the Galapagos Rift in the eastern Pacific, and the general area of our drill sites there. 
1979; Batiza and Johnson, this volume; Lonsdale and Spiess, 1979). Most of these are from the Siqueiros fracture zone. The following discussion will deal with all available rocks from this area, as well as with the rocks drilled from the Galapagos Rift.

\section{THE PROBLEM OF OCEANIC FERROBASALT}

A useful starting point is the question of oceanic ferrobasalt. Quartz-normative tholeiitic basalts showing striking enrichments in total $\mathrm{Fe}$ and $\mathrm{TiO}_{2}$ were drilled at several sites during Leg 54, and appear to be more abundant on the East Pacific Rise and other eastern Pacific spreading centers than on the Mid-Atlantic Ridge (Bass, 1971; Scheidegger, 1973; Clague and Bunch, 1976; Melson et al., 1976; Natland, 1978a). Most workers consider that ferrobasalts are derived from more primitive olivine tholeiite liquids by crystal fractionation. To some extent, this belief is based on an analogy with the typical trend of iron enrichment observed in dolerites (e.g., Fenner, 1929; Kuno, 1968) and mafic intrusions such as the Skaergaard (Wager and Deer, 1939; Wager and Brown, 1967). The Skaergaard is evidence that ironenrichment fractionation should occur among sea-floor basalts, since the intrusion evidently had a parental composition nearly identical to that inferred for abyssal tholeiites (Irvine, 1979). Experimental evidence has long since been gathered to show that iron enrichment leading to quartz-normative residual liquids would ensue from crystal fractionation in analogs to basalt systems under appropriate conditions of crystallization (e.g., Bowen and Schairer, 1935; Osborne, 1959, 1962). Clague and Bunch (1976) lent computational credence to the notion that abyssal ferrobasalts are derived from olivine tholeiites by crystal fractionation. They showed that close matches to actual compositions could be obtained by models in which fractionation is dominated by plagioclase and clinopyroxene, with lesser olivine. On this basis, they disputed the earlier suggestions of Bass (1971) and Scheidegger (1973) that ferrobasalts are derived directly by partial melting in the mantle.

In view of the tendency toward iron enrichment in small mafic magma bodies such as dikes, why ferrobasalts are so rare on the Mid-Atlantic Ridge is a particular problem. Bryan (1979) provided analyses of ferrobasaltic glasses from the walls of the FAMOUS Rift, but their general abundance must still be considered low. Typical levels of crystal fractionation calculated by least-squares computer techniques from similar olivine tholeiite parents are 30-40 per cent for the Mid-Atlantic Ridge (Bryan et al., 1979) and $60-80$ per cent for the East Pacific Rise and Galapagos Rift (Clague and Bunch, 1976). The most evolved glass reported by Bryan (1979) has $\mathrm{TiO}_{2}$ contents of 1.97 per cent and total iron as $\mathrm{FeO}^{*}$ of 12.00 per cent. These are levels below those in basalts from at least six localities in the Siqueiros area alone.

From DSDP data, some idea of the disparity between the Mid-Atlantic Ridge and East Pacific Rise can be obtained from Figure 2, which shows histograms of the $\mathrm{Mg} /(\mathrm{Mg}+\mathrm{Fe})$ ratio versus percentage of meters cored (rather than number of analyses). The ratio is an index

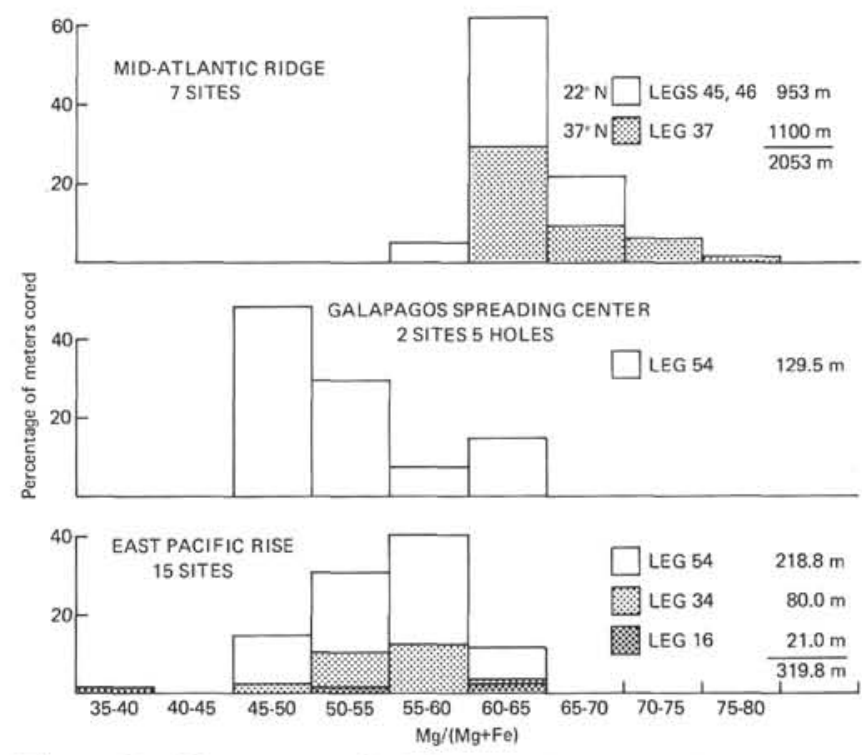

Figure 2. Histogram of $\mathrm{Mg} /(\mathrm{Mg}+\mathrm{Fe})$ versus percentage of meters cored for DSDP basalts from the MidAtlantic Ridge, the East Pacific Rise, and the Galapagos Rift, from Natland (1978a). Histogram is constructed by weighting according to the thickness of defined chemical units rather than number of analyses.

of both $\mathrm{Mg}$-depletion and Fe-enrichment. Although the total penetration by drilling on the East Pacific Rise is considerably lower than on the Mid-Atlantic Ridge, there is little doubt that East Pacific Rise basalts tend to be more evolved. There is scarcely 10 per cent overlap in compositions. Ferrobasalts, which have $\mathrm{Mg} /(\mathrm{Mg}+\mathrm{Fe})$ ratios of less than about 0.5 , are the most abundant rock type recovered by drilling in the Pacific, but have not been drilled at all along rifted portions of the MidAtlantic Ridge. The Galapagos Rift data encompass only two sites, at one of which essentially the same, strongly evolved, ferrobasalt was recovered in four closely spaced holes. Nevertheless, the basalts of the remaining site, Site 425 , are still more evolved than those of the Mid-Atlantic Ridge, as is readily apparent on Figure 2.

Rosendahl (1976) and Batiza et al. (1977) linked the occurrence of ferrobasalt on the East Pacific Rise to the presence of a geophysically detectable shallow axial magma chamber. They considered this to be the logical place in which fractionation occurs, and implied that residence time in the magma chamber was the critical factor determining the degree of fractionation attained. On the other hand, Rosendahl (1976) believed that the scarcity of ferrobasalts on the Mid-Atlantic Ridge is because there is no such large magma chamber beneath the floor of its axial rift. With this, the problem of oceanic ferrobasalt was placed squarely in the midst of the dynamic problem of the formation of oceanic crust, and of the explanation for the sharp contrasts in physiography and structure between slow- and fast-spreading ridges.

Because of the uniform seismic structure of the crust on the flanks of the East Pacific Rise, Rosendahl (1976) 
argued that the magma chamber beneath the Rise crest has been a steady-state feature for at least the past 4 m.y. Consolidation of magmas along its walls produces much of the crust and is constantly matched by supply of new magma to its interior as spreading proceeds. Similar arguments for steady-state magma chambers in spreading situations have been made based on structural analysis of portions of ophiolites (e.g., Cann, 1974; Kidd, 1977; Allen, 1975). From the petrologic and geochemical point of view, existence of a steady-state magma chamber has been proposed to explain unusual enrichments in low-partition-coefficient trace elements not possible to attain by closed-system fractionation (O'Hara, 1977; Bryan et al., 1979), although the efficacy of this has recently been disputed (Langmuir, 1979). Additionally, computations have been made to show that steadystate magma chambers which are recurrently and steadily replenished will approach a nearly uniform steadystate bulk composition (Usselman and Hodge, 1978; Cann, in press). These models and calculations entail that melts within the chamber be thoroughly mixed with each increment of magma supplied from sources in the mantle.

All of these possibilities are fertile ground for speculation regarding the origin of ferrobasalts and the causes for the petrologic contrasts between slow and fastspreading ridges. The concern of this chapter will be to use petrological and geological data to assess how and where ferrobasalts evolve in the oceanic crust; how, if at all, they are related to magma chambers; and finally, why they are so rare on the Mid-Atlantic Ridge.

\section{FERROBASALTS ON THE EAST PACIFIC RISE AND GALAPAGOS RIFT}

At this point it may be useful to develop a working definition of ferrobasalt and at the same time point out an important contrast between the East Pacific Rise and Galapagos Rift. Not all workers have chosen to call abyssal tholeiites with enrichment in iron and $\mathrm{TiO}_{2}$, ferrobasalts. Melson et al. (1976) designated them "FETI basalts" in distinction from rare iron-enriched basalts in which $\mathrm{TiO}_{2}$ was still low. Figure 3 shows the strong correlation between the abundances of $\mathrm{TiO}_{2}$ and total iron as $\mathrm{FeO}^{*}$ for East Pacific Rise and Galapagos Rift glasses (Fig. 3a; data and notation from Natland and Melson, this volume) and basalts (Fig. 3b; averaged from data in Joron et al., this volume). However, there are two separate trends-one for the Galapagos Rift, and one for the East Pacific Rise. (Transitional and alkalic basalt glasses, groups $\mathrm{G}$ and $\mathrm{L}$, form yet a third grouping on Fig. 3a). At a given level of $\mathrm{FeO}^{*}$, Galapagos Rift basalts and glasses have about 0.5 per cent less $\mathrm{TiO}_{2}$ than East Pacific Rise basalts and glasses, or somewhere between 25 and 50 per cent less $\mathrm{TiO}_{2}$ depending on the sample. This difference is an important reason why the term "ferrobasalt" is preferable to "FETI basalt." What would be a FETI basalt on the East Pacific Rise would not necessarily be on the Galapagos Rift, even though the basalts might be comparably evolved from their respective parents. Obviously, FETI basalts even so still occur on the Galapaos Rift. But only those with
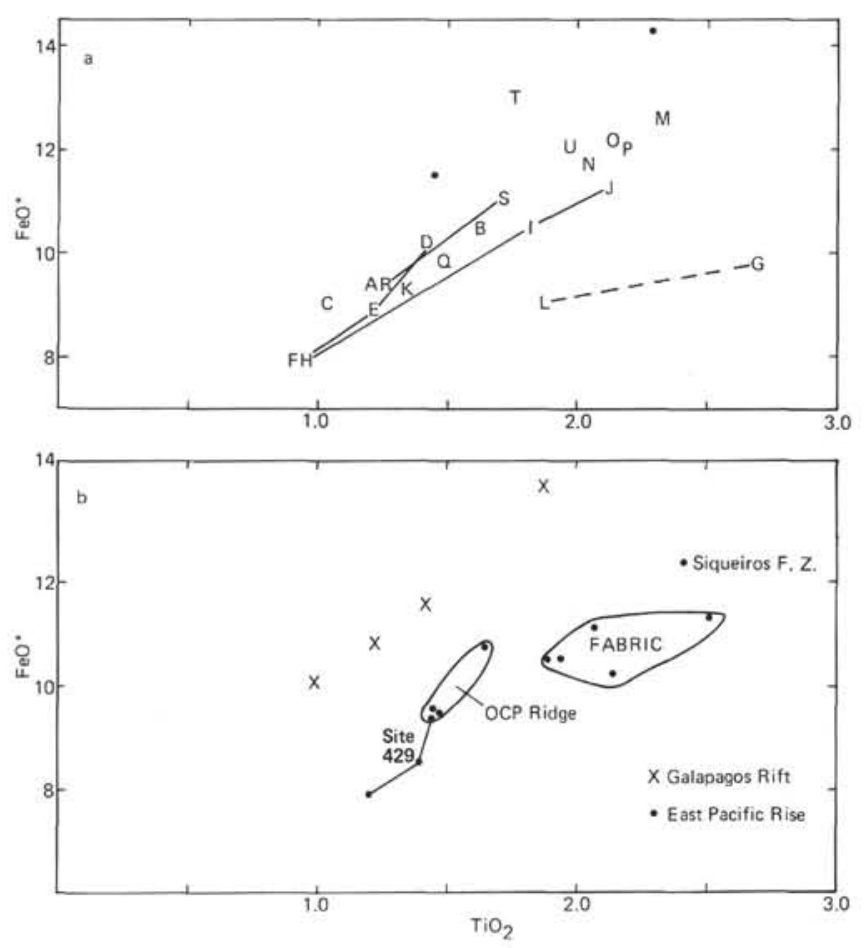

Figure 3. $\mathrm{FeO}$ * (total iron as $\mathrm{FeO}$ ) versus $\mathrm{TiO}_{2}$ for (a) East Pacific Rise and Galapagos Rift glasses (Natland and Melson, this volume; Melson et al., 1976) and (b) average East Pacific Rise and Galapagos Rift basalts drilled during Leg 54 (Joron et al., this volume). Letters identifying glass groups as in Natland and Melson (this volume). Solid lines link glass groups or averages recovered in the same dredge or drill site. Dashed line links transitional-alkalic glass groups.

extremely high $\mathrm{FeO}$ * have higher $\mathrm{TiO}_{2}$ than, say, the average mid-ocean ridge basalt (MORB) of Kay et al. (1970), or the average oceanic tholeiite of Engel et al. (1965) which are olivine tholeiite compositions.

The low $\mathrm{TiO}_{2}$ in the Galapagos Rift basalts compared with the East Pacific Rise suite is matched by lower $\mathrm{Zr}$, $\mathrm{K}_{2} \mathrm{O}, \mathrm{P}_{2} \mathrm{O}_{5}$, rare-earth element, and other low-partitioncoefficient element abundances. All of these show strong positive covariance with each other according to the degree of iron enrichment, but none of them, when compared with a single standard such as average MORB, would accurately indicate the degree of evolution from a primitive parent. However, $\mathrm{FeO}^{*}$ does.

The lower $\mathrm{TiO}_{2}$ and low-partition-coefficient trace element abundance in the Galapagos Rift basalts have been interpreted by Srivastava et al. (this volume), Hekinian and Morel (this volume), and Natland and Melson (this volume) to indicate a fundamentally higher degree of melting beneath the Galapagos Rift than beneath the East Pacific Rise. Based on $\mathrm{K}_{2} \mathrm{O}, \mathrm{P}_{2} \mathrm{O}_{5}$, or $\mathrm{Zr}$, a primitive Galapagos Rift tholeiite would represent about 50 per cent greater melting of a homogeneous source than a comparable primitive East Pacific Rise tholeiite (Natland and Melson, this volume). Joron et al. (this 
volume) found little difference between basalts of the Rise and the Rift in the ratios of those trace elements with the lowest partition coefficients. The mantle sources of the two suites thus appear to be about comparably depleted.

Figure 3 therefore demonstrates that the Galapagos Rift has a range of basalts just about as evolved from parental compositions as East Pacific Rise basalts. At Site 424, the basalts have higher $\mathrm{FeO}^{*}$ than at any of the East Pacific Rise sites, but they only have about 1.9 per cent $\mathrm{TiO}_{2}$. And even though none of the basalts at Site 425 has more than 1.42 per cent $\mathrm{TiO}_{2}, \mathrm{FeO}^{*}$ is as high as in all basalts drilled at flank sites on the East Pacific Rise except Site 429.

In thin sections, ferrobasalts from both localities are clinopyroxene-plagioclase basalts that lack olivine in coarser grained samples. Olivine does appear to form metastably in ferrobasalts at high undercoolings (represented by small pillows and thin sheet flows), since skeletal olivines occur in glassy and spherulitic samples (Natland, this voume). A reasonable petrographic definition for ferrobasalt thus seems to be that they are basalts that lack olivine formed under near-equilibrium conditions, are either aphyric or have plagioclase and clinopyroxene microphenocrysts, often clumped togeth$\mathrm{er}$, and, in coarser grained samples, have abundant coarse, skeletal titanomagnetite. Among East Pacific Rise samples, this occurs when the basalts have at least 1.8 per cent $\mathrm{TiO}_{2}$ and 10.5 per cent $\mathrm{FeO}^{*}$. For Galapagos Rift samples, $\mathrm{FeO}^{*}$ is comparable, but $\mathrm{TiO}_{2}$ is only about 1.3 per cent. In both cases, $\mathrm{MgO}$ is about 7.5 per cent or less.

\section{DISTRIBUTION OF DREDGED AND DRILLED BASALTS ON THE EAST PACIFIC RISE AND GALAPAGOS RIFT}

The distribution of rock types recovered from the Siqueiros region of the East Pacific Rise is shown on Table 1. This table uses $\mathrm{TiO}_{2}$ as an index of evolution of basalts toward ferrobasalt composition within the East Pacific Rise suite, based on Figure 3 and our previous discussion. $\mathrm{TiO}_{2}$ can be analyzed very precisely, and is perhaps the best major-oxide discriminant of distinctive basalt magma types. As shown on Table 1, 38 distinct chemical types, each apparently representing a separate eruptive event, have been recovered from the Siqueiros region.

There are two important features to Table 1. First, although there are exceptions, it is evident that high- $\mathrm{TiO}_{2}$ ferrobasalts predominate on the flank and crest of the East Pacific Rise, and that low- $\mathrm{TiO}_{2}$ olivine tholeiites predominate in the fracture zone. Second, considering the exceptions, it is evident that flank and crest ferrobasalts are closely associated with at least a small proportion of olivine tholeiite.

Table 2 is a compilation similar to that of Table 1 for other sites on crust produced at the crest of the East $\mathrm{Pa}$ cific Rise, drilled during earlier DSDP Legs, plus dredge stations from nearly the fastest spreading portion of the rise near $3^{\circ} 25^{\prime} \mathrm{S}$. For these basalts, both $\mathrm{TiO}_{2}$ and $\mathrm{FeO}^{*}$ abundances are comparable to basalts from the $\mathrm{Si}$ - queiros region; hence, the abundance of $\mathrm{TiO}_{2}$ can be used in the same way to express the degree of evolution toward ferrobasalt compositions. This table is further evidence that ferrobasalts occur at flank localities of the East Pacific Rise, but also that ferrobasalts are closely associated with other, less evolved basalts.

On the basis of our earlier discussion, we cannot use $\mathrm{TiO}_{2}$ directly to compare the Galapagos Rift basalts with East Pacific Rise basalts, but considering the abundances of iron, and adjusting for the difference in $\mathrm{TiO}_{2}$, we can say that a highly evolved ferrobasalt was cored at Site 424, and that three basalt types, more or less comparable with East Pacific Rise ferrobasalts, were cored at Site 425 (Fig. 3).

These distributions are important, because if all of the rock types that occur on the flanks of the Rise and the Rift were erupted from their respective magma chambers, then ferrobasalt cannot be the steady-state product of either one of them. To evaluate this, it is necessary to consider geological aspects of magmatism on the East Pacific Rise and the Galapagos Rift. For this, we can take advantage of detailed near-bottom surveys of the axial regions of both the Rise and the Rift nearest our drill sites, and an analogous portion of the Rise near $3^{\circ} 25^{\prime} \mathrm{S}$. The East Pacific Rise will be discussed first.

\section{AXIAL MAGMATISM ON THE EAST PACIFIC RISE}

The East Pacific Rise in the vicinity of our drill sites has a spreading half rate of just under $6 \mathrm{~cm} / \mathrm{y}$. and a crestal region with two general geomorphologies. One typical geomorphology, near $8^{\circ} 45^{\prime} \mathrm{N}$, has a roughly triangular or dome-shaped cross section with smooth slopes rising 150-200 meters above surrounding faultblock abyssal hill topography (Figure 4a). In a detailed near-bottom study of a similar feature on the East $\mathrm{Pa}$ cific Rise crest at $3^{\circ} 25^{\prime} \mathrm{S}$, Lonsdale (1977a) likened it to a shield volcano. He documented many landforms also found, for example, on the Kilauea east rift. The most important of these is a narrow (100-250-m wide), shallow 10-35-m deep) summit graben, the locus of axial fissure eruptions. At a dredge station precisely within this graben (Lonsdale, 1977a, fig. 11) ferrobasalts were recovered (Natland and Melson, this volume; glass group U).

Although most of the axial dome at $3^{\circ} 25^{\prime} \mathrm{S}$ has smooth slopes constructed from fissure eruptives, there are small secondary volcanic peaks between 30 and 100 meters high that could have formed at the rise crest or on the flanks of the dome. Extrusives from these cover perhaps 5 per cent of the area of the deep-tow survey (Lonsdale, 1977a, fig. 6). Only one secondary peak appears to have formed off the axial dome, as evidenced by unusually thin sediments in its vicinity.

The other axial geomorphology in the Siqueiros region is a prominent plateau (Figure $4 \mathrm{~b}$ ), wider at its base than the axial dome. A deep-tow survey of this feature shows that it is bounded by prominent faults with throws of up to 100 meters (Lonsdale and Spiess, this volume). The plateau has a 1-to 2-km wide crestal rift zone about $1.5 \mathrm{~km}$ east of its center, with summit grabens, pillow 
TABLE 1

Distribution of Distinct Chemical Types of Basalt at all DSDP Sites and Dredge Stations in the Siqueiros (PT-4 Survey) Region, Based on $\mathrm{TiO}_{2}$ Contents

\begin{tabular}{|c|c|c|c|c|c|c|}
\hline \multirow[b]{2}{*}{ Dredge Station or Hole } & \multirow{2}{*}{$\begin{array}{c}\text { Distance From Rise } \\
\text { Crest (EPR sites } \\
\text { only) }\end{array}$} & \multicolumn{4}{|c|}{$\begin{array}{c}\mathrm{TiO}_{2} \\
\text { Abyssal Tholeiite Suite }\end{array}$} & \multirow{2}{*}{$\begin{array}{c}\text { Transitional/ } \\
\text { Alkalic }\end{array}$} \\
\hline & & $0.8-1.4$ & $1.4-1.9$ & $1.9-2.4$ & $>2.4$ & \\
\hline \multicolumn{7}{|l|}{ East Pacific Rise } \\
\hline SD-5 & $0-5$ & & 1 & 1 & & \\
\hline $423^{a}$ & 101 & & & 1 & & \\
\hline DS-3 & $104-101$ & 1 & 1 & 1 & & \\
\hline DS-5 & $104-103$ & & & 1 & & \\
\hline DS-1 & $108-104$ & & 1 & & & \\
\hline $421^{\mathrm{a}}$ & 209 & & & 2 & & \\
\hline $420^{\mathrm{a}}$ & 213 & & & 1 & & \\
\hline $429^{a}$ & 276 & 1 & 1 & & & \\
\hline \multicolumn{7}{|l|}{ OCP Ridge } \\
\hline $422^{\mathrm{a}}$ & & & 2 & & & \\
\hline $428^{a}$ & & & 1 & & & \\
\hline $428 \mathrm{~A}^{\mathrm{a}}$ & & & 1 & & & \\
\hline DS-4 & & 1 & & & & 1 \\
\hline \multicolumn{7}{|l|}{ Seamounts } \\
\hline IMED-1 & & 1 & & & & \\
\hline SD-8 & & 1 & & & & 1 \\
\hline QBR-22 & & 1 & & & & \\
\hline \multicolumn{7}{|l|}{ Siqueiros Fracture Zone } \\
\hline QBR-19 & & 1 & & & & \\
\hline QBR-17 & & 1 & & & & \\
\hline SD-7 & & 2 & 1 & & & \\
\hline SD-6 & & 1 & 1 & & 1 & \\
\hline SD-3 & & 2 & & & & \\
\hline CD-1 & & 2 & & & & \\
\hline SD-4 & & 1 & & & & \\
\hline $427 \mathrm{a}$ & & & & & 1 & \\
\hline Totals & & 16 & 9 & 7 & 2 & 2 \\
\hline
\end{tabular}

${ }^{\mathrm{a}}$ DSDP sites, data this volume.

Note: Data for dredges SD, QBR, and CD in Batiza et al., 1977. Data for dredges DS in Johnson, 1979. Data for dredge IMED-1 in Lonsdale and Spiess, 1979.

walls, and small axial peaks. It is the principal locus of fissure eruptions. Beyond $2 \mathrm{~km}$ from the rift zone, the axial plateau is broken increasingly by faults, fissures, and graben-type structures. At its edges, there are secondary volcanic peaks partly covering the major fault scarps. The surrounding sea floor is a bit more rugged than the sea floor adjacent to portions of the Rise with an axial dome.

It is evident from these descriptions that fissure eruptions are constrained within narrow zones on axial "shield volcanoes" and that secondary, off-axis eruptions are relatively minor. However, where there is an axial plateau, the zone of fissure eruptions is 5 to 10 times wider, and eruptions away from this zone may be fairly common, especially at the margins of the plateau. A dredge station across a portion of the axial plateau (dredge SD-5 of Batiza et al., 1977) recovered two distinct basaltic types-one an olivine tholeiite, the other a ferrobasalt (Table 1). It is not possible to state from which particular landforms these rocks were dredged.

Away from the axial plateau, Lonsdale and Spiess (this volume) note no small-scale features that would
TABLE 2

Distribution of Distinct Chemical Types of Basalt on the East Pacific Rise Flanks at Locations outside the PT $=4$ (Siqueiros) Survey Area, Based on $\mathrm{TiO}_{2}$ Contents

\begin{tabular}{|c|c|c|c|c|c|}
\hline \multirow{3}{*}{$\begin{array}{c}\text { Dredge } \\
\text { or } \\
\text { Drill } \\
\text { Site }\end{array}$} & \multicolumn{4}{|c|}{$\mathrm{TiO}_{2}(\%)$} & \\
\hline & \multicolumn{4}{|c|}{ Abyssal Tholeiite Suite } & \\
\hline & $0.9-1.4$ & $1.4-1.9$ & $1.9-2.4$ & $>2.4$ & \\
\hline $159^{a}$ & & & & 1 & \\
\hline $160^{\mathrm{a}}$ & & & & 1 & \\
\hline $161^{\mathrm{a}}$ & & 1 & & & \\
\hline $162^{a}$ & & 1 & & & Number of \\
\hline $163^{\mathrm{a}}$ & 3 & 1 & & & Distinct \\
\hline $319^{b}$ & 1 & 1 & 1 & & Chemical \\
\hline $320^{\mathrm{b}}$ & & 1 & 1 & & Types \\
\hline $321^{\mathrm{b}}$ & & & 1 & & \\
\hline PL-1DC & & & 1 & & \\
\hline $\mathrm{P} 1-2 \mathrm{D}^{\mathrm{d}}$ & 1 & & & & \\
\hline
\end{tabular}

aEast Pacific Rise Leg 16 (Yeats et al., 1973).

bNazca Plate Leg 34 (Rhodes et al., 1977).

CEast Pacific Rise $3^{\circ} 25^{\prime} \mathrm{S}$ (Natland and Melson, this volume).

dQuebrada fracture zone $3^{\circ} 40^{\prime}$ S (Lonsdale and Spiess, 1979). 
represent volcanism burying abyssal hills. One major feature, OCP Ridge (Fig. 1), is capped with transitional basalts (Johnson, 1979; Batiza and Johnson, this volume) that did not reach moat-like depressions on its flanks (Natland and Melson, this volume). Another pair of large seamounts, symmetrically disposed on either side of the rise axis, are inferred by Lonsdale and Spiess (1979) to have drained part of the axial magma chamber. Olivine tholeiites were recovered in a dredge across the summit of one of them (Table 1).

Site selection for DSDP Sites 420, 421, 423, and 429 and for site survey dredges DS-1, DS-3, and DS-5 (Table 1) was based on surface-ship profiles that showed a particular, irregular, somewhat fuzzy acoustic return from basement. This is typical of the widespread lineated, fault-block, abyssal hill topography in the area, that which Rosendahl and Dorman (this volume) term "normal fabric." The DSDP sites were in small, sedimented, depressions ("'grabens"). There is no evidence that any of these locations were covered with volcanics erupted away from the axial plateau. Therefore, almost certainly, all of the rock types found at these localities, as well as in dredge SD-5 on the axial plateau, either erupted in the fissure zone near the center of the plateau, or within a few kilometers of that fissure zone. The latest any of them could have erupted was at the margins of the plateau, as secondary volcanic peaks.

By narrowing the probable locus of magmatism for the basalts we have sampled to the axial plateau, it becomes a virtual certainty that all of these basalts originated in, or had parents originating in, the axial magma chamber. The axial plateau of the East Pacific Rise in the Siqueiros region is where Orcutt et al. $(1975,1976)$ and Rosendahl et al. (1976) detected a magma reservoir in the crust by seismic refraction techniques. In the view of Rosendahl (1976) and Sleep and Rosendahl (1979), the entire axial plateau owes its relief to this crustal magma reservoir, reflecting the isostatic response of the crustal lid resting on a lens of material that is at least 30 per cent molten. They model this lens as thinning toward the margins of the plateau, but spanning its entire width. Lonsdale and Spiess (this volume) argued on this basis that even the secondary volcanic peaks on the margins of the plateau tapped into the magma reservoir.

For all these reasons, it is evident that ferrobasalt cannot be the steady-state product of the axial magma reservoir on the East Pacific Rise near $9^{\circ} \mathrm{N}$.

\section{AXIAL MAGMATISM ON THE GALAPAGOS RIFT}

The Galapagos Rift at the longitude of our drill sites $\left(86^{\circ} \mathrm{W}\right.$ ) has a half-spreading rate of $3.35 \mathrm{~cm} / \mathrm{y}$ (Klitgord and Mudie, 1974), but it possesses neither the prominent axial dome or plateau of faster spreading ridges, nor the pronounced axial rift of the slow-spreading Mid-Atlantic Ridge (Figure 5). The rift axis has been intensively studied by means of deep-tow surveys, photo-transverses with the Angus towed camera system, a U.S. Navy multinarrow beam sonar survey, and submersible observations. Using parts or all of these data, Lonsdale (1977b), Crane (1978), Ballard et al. (1979), and van Andel and Ballard (1979) have described landforms at the rift axis similar to those on the summit of the East Pacific Rise, including a central graben which is the locus of fissure eruptions. The topography is divided into a series of lineated, anti-symmetric ridges and troughs with about 50-meters relief. Van Andel and Ballard (1979) see these as forming by alternating periods of slow and rapid extension in any one part of the rift valley, and by having the locus of rapid extension shift to one side or the other of accumulated volcanic piles. Crane (1979) has suggested alternatively that the antisymmetric topography is related to periodic propagation of magma pulses down the axis of the rift. In both cases, the topography is argued to be sensitively dependent on a shallow magma chamber whose top is 0.5 to $1.0 \mathrm{~km}$ deep and spanning the 4-km width between the walls of the rift. Rosendahl et al. (1978) have detected such a magma chamber by seismic refraction techniques along this part of the rift.

For the Galapagos Rift, more so than for the East Pacific Rise, there is evidence for considerable variability in basalt compositions erupted within the confines of the rift. Basalts with $\mathrm{TiO}_{2}$ ranging from about 1.3 to 2.6 per cent and $\mathrm{FeO}^{*}$ from 11.3 to 15.7 per cent have been sampled by submersible (data of J. Corliss cited in Ballard et al., 1979). Lavas of this entire chemical range have been recovered from pillows, sheet flows, and columnar basalts. Since van Andel and Ballard (1979) relate sheet flow eruption to periods of rapid extension and to a thin crustal lid over the magma chamber, there is no doubt that all of these rock types can be erupted over the very top of the magma chamber in the center of the rift. Here, too, then, there is no single steady-state product of the axial magma chamber.

\section{UNIFORMITY OF PARENTAL COMPOSITIONS ON THE EAST PACIFIC RISE}

One aspect of the petrology of ferrobasalts that can only be discussed for the East Pacific Rise, where there are sufficient data, is that they can have remarkably similar compositions. Natland and Melson (this volume) found that, within the precision of the electron microprobe glass-analysis technique, essentially identical ferrobasalt compositions were drilled at Sites 420,421 , and 423 , which span crust ranging from 1.7 to $3.4 \mathrm{~m}$.y. old. These differ in only minor ways, falling outside the limits of resolution for only a single oxide each, from glasses recovered in dredge stations on the rise crest at $3^{\circ}$ $25^{\prime} \mathrm{S}$, and at $13^{\circ} 13^{\prime} \mathrm{S}$. Some idea of this similarity can be seen on Figure 6, which shows a very tight bunching for quartz-normative compositions, but a wide scatter for olivine-normative glasses obtained from both the rise flanks and the Siqueiros fracture zone. The similar glass compositions from Sites 420,421 , and 423 (glass groups $\mathrm{N}, \mathrm{O}$, and $\mathrm{P}$ ) plot very close to each other, even within the closely bunched quartz-normative grouping. Whole-rock compositions of these rocks also have very similar trace element abundances (Natland and Melson, this volume).

These similar glass groupings are not necessarily the most nor the least evolved compositions recovered from those sites, or from the region. They represent, certainly 


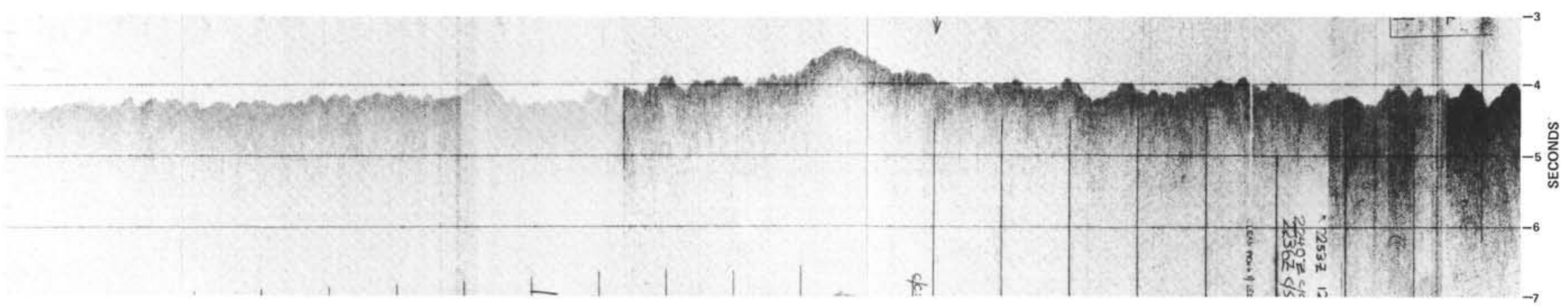

East-west Profile near $9^{\circ} \mathrm{N}$

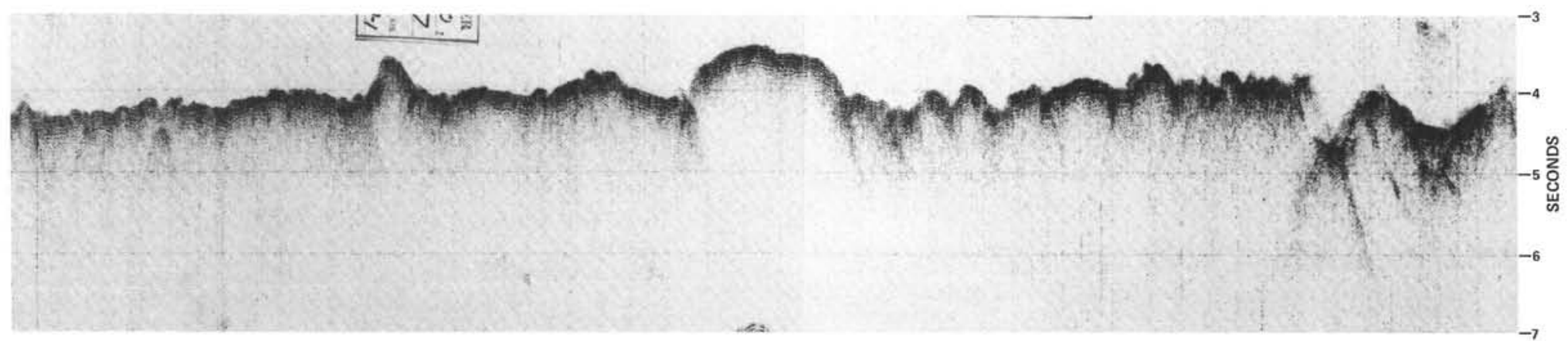

East-west Profile near $8^{\circ} 30^{\prime} \mathrm{N}$

Figure 4. Glomar Challenger air-gun profiles across the crest of the East Pacific Rise obtained during Leg 54. The upper profile shows a dome-shaped crestal geomorphology, with adjacent fault-block topography subsiding and becoming covered with sediments away from the rise crest. The lower profile shows a plateau-like axial block and represents the crestal geomorphology between about $8^{\circ} 35^{\prime} \mathrm{N}$ and the Siqueiros fracture zone at about $8^{\circ} \mathrm{N}$. 


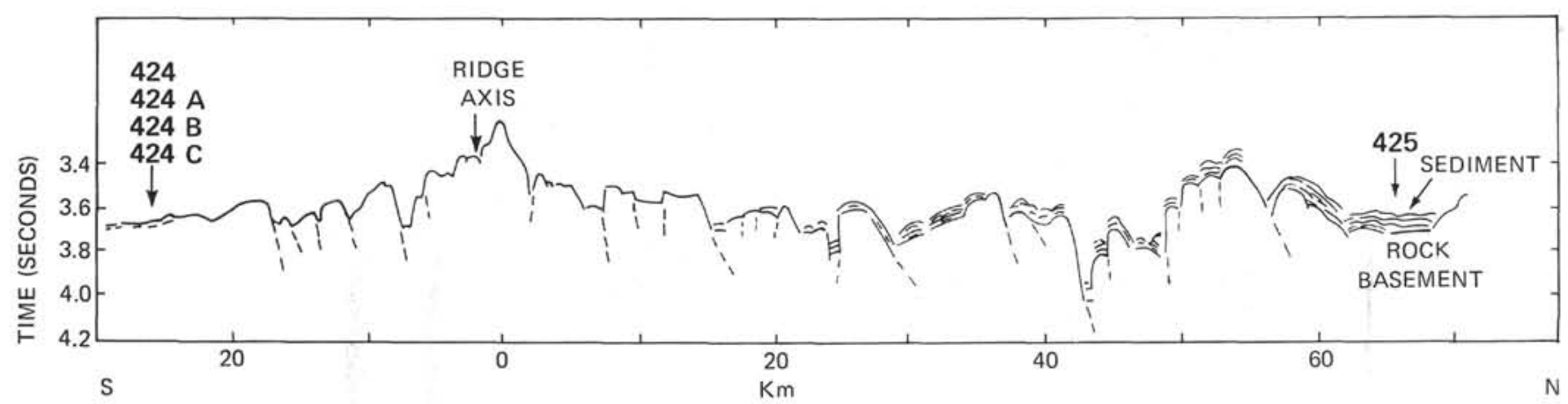

Figure 5. Line drawing of Glomar Challenger air-gun profile between Sites 424 and 425, showing fault-block structure and sediment distribution on either side of the Galapagos Rift axis. Locations of the sites are also shown. Note inward-facing fault scarps on either side of the rift axis. Dashed lines are extrapolated faults into basement based on surface topography.

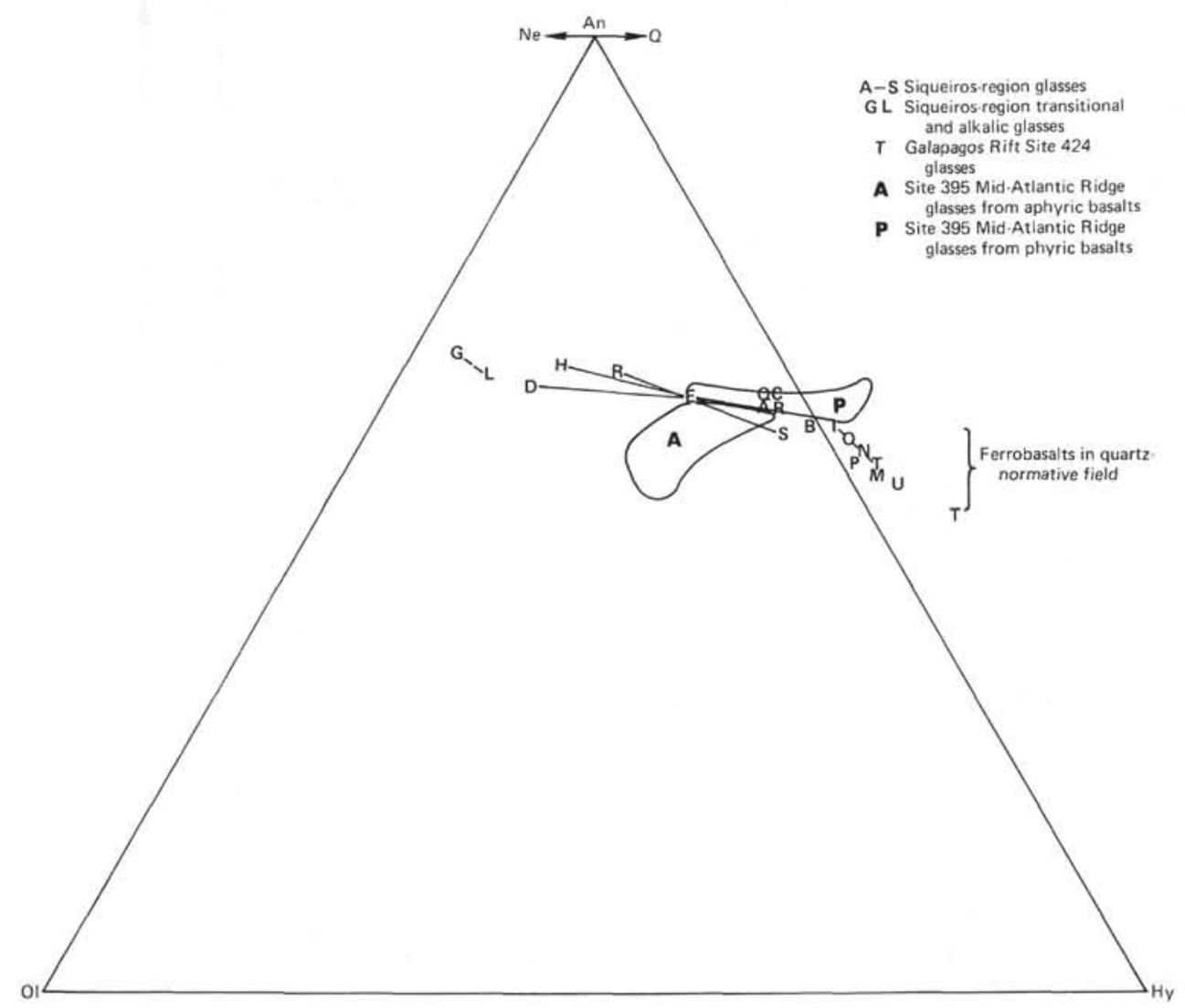

Figure 6. Glass samples plotted in the normative quartz-hypersthene-olivine-anorthite-nepheline system. Symbols as in Figure $3 a$. Norms were calculated assuming $\mathrm{Fe}^{3+} / \mathrm{Fe}^{2+}$ (atomic) $=0.18$ (following Presnall et al., 1979). Solid lines link glass groups recovered at the same dredge or drill sites. Dashed line links transitionalalkalic glass groups.

somewhat fortuitously, a common point along a single fractionation pathway spanning from olivine tholeiites to ferrobasalts. It is crucial to understand that these are not some ultimate, residual composition (as, for example, granites are in Petrogeny's residual system). The significance of these similarities is twofold. They require, first of all, that there be one fundamental olivine tholeiite parental composition supplied along this and other parts of the rise crest, and, in the Siqueiros region, that supply of this parental composition has persisted for at least several million years. Secondly, starting from this uniform parent, a remarkably constant range of physical and thermal conditions within the magma chamber and the conduit systems leading to the sea floor permits virtually no temporal variation in the course of subsequent fractionation. It is not as though 
such variation cannot occur. At least one pair of ironenriched glass compositions (groups I and J on Fig. 6 from dredge DS-3) have compositions that diverge significantly from the more typical trend (Natland and Melson, this volume). Evidently, they were produced by fractionation processes at higher pressures, or involving an additional phase such as titanomagnetite. In short, the variations that can occur evidently do not do so very often. This is a remarkable indication of just how uniform conditions in the magma chamber and conduit system can actually be.

The uniformity of parental compositions evidently required for ferrobasalts is somewhat at odds with the indications of diversity of composition among olivine tholeiites recovered primarily from the fracture zone. The scatter among the olivine tholeiites shown on Figure 6 is an indication that many of them could not be parental to axial ferrobasalts. In detail, summarizing from Natland and Melson (this volume), many of the olivine tholeiite glasses have too much $\mathrm{TiO}_{2}$, and $\mathrm{K}_{2} \mathrm{O}$, and $\mathrm{P}_{2} \mathrm{O}_{5}$ to be plausible parents to any of the more fractionated olivine basalts or ferrobasalts of the rise crest or flanks. Some also have lower $\mathrm{CaO} / \mathrm{Al}_{2} \mathrm{O}_{3}$, a difference which cannot be removed by fractionation of their liquidus phases, olivine and chromian spinel, in a shallow axial magma chamber. Natland and Melson (this volume) infer that the differences in compositions among olivine tholeiites require both variations in the degree of melting, and probably the depth of melting, in the mantle beneath the fracture zone.

There appear to be two ways for an extremely uniform rise crest parental olivine tholeiite to develop. The first is to have extremely uniform conditions of melting (depth, degree of melting) of a homogeneous source. The second is to homogenize melts arriving at the base of the magma chamber by efficient mixing. Both could act in concert. Uniform melting conditions for primitive rise and ridge tholeiites have been postulated by Presnall et al. (1979) who argue that a near-invariant thermal cusp exists at the transition between plagioclase lherzolite and spinel lherzolite in the mantle. Their rise and ridge melting hypothesis is that this cusp stabilizes the oceanic geotherm, which intersects the solidus at the cusp at a pressure of about $9 \mathrm{kbars}$ (about $30 \mathrm{~km}$ deep). The critical feature of such melting is that, until a major phase is exhausted, melts will have nearly identical compositions regardless of the proportion of phases in the source (Presnall, 1969). Variations would occur in the abundances of minor elements, which could be variably diluted by different degrees of partial melting (explaining, for example, the contrast between Galapagos Rift and East Pacific Rise basalts). But even these have not occurred along the East Pacific Rise. It would incidently be difficult for such stabilized melting to occur beneath older, cold and thickened, lithosphere or in regions with strong lateral thermal gradients. Off-axis seamount and fracture-zone volcanism therefore should produce olivine basalts of variable compositions which are different from olivine tholeiites produced beneath the rise crest (for further discussion of this, see Natland and Melson, this volume).
The importance of magma mixing within the axial magma chamber in ensuring a homogeneous parental olivine tholeiite composition is difficult to assess, but may be even greater than that of uniform conditions of melting. The magma chambers along segments of the East Pacific Rise appear to be steady-state features that can underlie tens and even hundreds of kilometers of rise crest without a fracture zone offset (Lonsdale, 1978c). Interchange of magmas along the entire length of magmachamber segments should be a very efficient averaging mechanism, buffering primitive olivine-tholeiite magmas to a constant composition.

\section{MAGMA MIXING ON THE EAST PACIFIC RISE AND GALAPAGOS RIFT}

Melts rising from the mantle beneath the East Pacific Rise and the Galapagos Rift must intercept a considerable body of molten material in the axial magma chambers. It is inevitable that mixing of magmas occurs. Chemical data constrain what compositions can mix together, and this in turn can provide clues about the bulk composition of the melt in the magma chamber.

It is generally thought that primitive olivine tholeiites supplied to rises and ridges have liquid compositions with 10-12 per cent $\mathrm{MgO}, \mathrm{Mg} /(\mathrm{Mg}+\mathrm{Fe})=0.70-0.72$, and $\mathrm{Ni}$ abundances of $250-300$ parts per million (Frey et al., 1974; Rhodes and Dungan, 1979; Presnall et al., 1979). Although most of the basalts dredged and drilled from the crest and flanks of the East Pacific Rise are more evolved than this, one basalt-from dredge DS-3 (Johnson, 1979)-has a glass composition and Ni abundances comparable to these (Natland and Melson, this volume; glass group $\mathrm{H}$ ). Because of its location on the flanks of the rise, and its chemistry, we can presume that this is a reasonably unmodified parental composition for the rise tholeiite suite. It has the lowest $\mathrm{Y}, \mathrm{Zr}$, $\mathrm{Ce}, \mathrm{TiO}_{2}, \mathrm{P}_{2} \mathrm{O}_{5}$, and highest $\mathrm{Ni}$ abundances of all the basalts analyzed from the Siqueiros region (Batiza and Johnson, this volume; Natland and Melson, this volume).

Figure 7 summarized the possibilities for mixing this composition with other basalts from the East Pacific Rise inferred to have erupted on the axial plateau or shield volcano. Data are also plotted for basalts drilled from the Nazca Plate (Rhodes et al., 1977) and Galapagos Rift (Joron et al., this volume). None of these data points falls along a mixing trend between primitive olivine tholeiites (similar to the basalt from dredge DS-3) and ferrobasalts. Instead, all data points follow reasonable fractionation trends. To be sure, magma mixing could well occur between any two evolved compositions (for example, with Ni less than $100 \mathrm{ppm}$ ), and this fact could not be resolved on Figure 7. Just such magma mixing has been proposed for Site 425 Galapagos Rift basalts by Mattey and Muir (this volume). But Figure 7 definitely limits severely the extent of primitive olivine tholeiite that can be mixed with any ferrobasalt or even many intermediate basalts for both the East Pacific Rise and the Galapagos Rift. Within the precision of this figure, and of the analytical data, perhaps 5 per cent could 


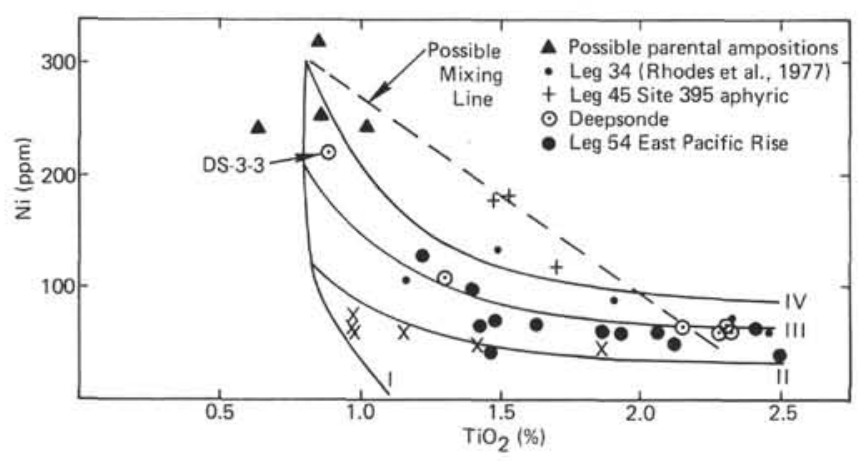

Figure 7. Ni versus $\mathrm{TiO}_{2}$ for samples from the East Pacific Rise (Joron et al., this volume; Natland and Melson, this volume), Galapagos Rift (Joron et al., this volume, representative analyses listed in Table 12 of the Galapagos Rift Site Report, this volume), and Nazca Plate (Rhodes et al., 1977). Mixing line, MidAtlantic Ridge data points, and calculated fractionation trends from Rhodes and Dungan (1979). Curve I-olivine fractionation only; Curves II, III-initial olivine fractionation followed by olivine-plagioclase fractionation in the ratio 1:4; Curve IV-olivine plagioclase fractionation in the ratio $1: 4 .\left(D_{N i}^{P I / l i q}=0.01\right.$; $D_{\mathrm{TiO}_{2}}^{\text {Pllliq }}=0.04 ; D_{\mathrm{Ni}}^{\text {ol/liq }}=12 ; D_{\mathrm{TiO}}^{\text {ol/liq }}=0.04$ ).

mix with ferrobasalt. But practically speaking, this is beyond the limits of detection. No mixing occurs that we can detect.

The consequences of this for the type of compositions that can evolve in a large, axial magma chamber are considerable. Not only can ferrobasalts not be the steady-state product of the $9^{\circ} \mathrm{N}$ East Pacific Rise axial magma chamber, but it is unlikely that the magma chamber even episodically ever evolved to ferrobasalt compositions. The latter conclusion depends partly on the former. It is theoretically possible that a magma chamber could evolve to a steady-state ferrobasalt composition, and be frequently replenished by very small increments of primitive olivine tholeiite, which would be difficult to detect as mixed with ferrobasalts (e.g., Cann, in press). But here, the sporadic association with ferrobasalts of axial olivine tholeiites, including the primitive olivine tholeiite from dredge DS-3, implies that even if the East Pacific Rise magma chamber episodically evolves to ferrobasalt compositions, these must be displaced at least occasionally by large increments of olivine tholeiite. This is difficult to imagine, since the magma chamber would first have to consolidate between 60 and 80 per cent of its original volume, as estimated by comparison with the fractionation calculations of Clague and Bunch (1976). This would have a disrupting effect on the continuity of crustal structure on the flanks of the rise crest not evident in the seismic refraction data (Rosendahl, 1976). And there should be large differences along strike in the dimensions of the rise crest axial shield volcano or plateau, since these are the isostatic expression of the magma chambers (Rosendahl, 1976) whose dimensions would be extremely variable. Large proportions of olivine tholeiite would have to be involved in mixing. This, if it occurred, would be readily detected on diagrams such as Figure 7. For these reasons, then, ferrobasalt does not appear to have evolved in the main body of the East Pacific Rise axial magma chamber at $9^{\circ} \mathrm{N}$.

\section{A MODEL FOR THE EVOLUTION OF EASTERN PACIFIC FERROBASALTS}

The explanation for lack of mixing between primitive olivine tholeiites and ferrobasalts at $9^{\circ} \mathrm{N}$ must be that ferrobasalts are effectively isolated from the main body of the axial magma chamber. They are therefore insulated from mixing with primitive melts. In the geometry we are dealing with, ferrobasalts would clearly have to evolve toward the top of the magma chamber or in the crustal lid above it. The physical aspects of this isolation are a matter of conjecture. Rosendahl (1976) calculated from seismic and topographic effects that the proportion of melt in the East Pacific Rise axial magma reservoir at $9^{\circ} \mathrm{N}$ is 30 per cent. If this is the case, then the magma chamber may have built within it a sufficiently effective filter to inhibit mixing between the top and bottom of the chamber. Cann (1974) and Allen (1975), however, argue that the magma chambers beneath at least fast-spreading rises must contain effectively 100 per cent melt, based on studies in the cumulate gabbroic and ultramafic portions of ophiolites. If this is the case, then ferrobasalts apparantly evolve in small, isolated bodies in the dilational zone of shattered dike rock, sheet flows, and pillow lavas that becomes saturated with magma in the crustal lid above magma chambers. The two cases may be equivalent. This is because the geophysical data specifying that the magma reservoir be, on average, 30 per cent molten, allow a small portion of the lens underlying the center of spreading to be 100 per cent molten, and to escape geophysical detection (B. Rosendahl, personal communiation). Evolution of fractionated magmas in rift zones is suggested in part by analogy to the dike injection zone along Kilauea volcano's east rift. In addition, ophiolites suggest that evolved magmas could also form in pockets of magma isolated by formation of cumulate masses of crystals, as the walls of magma chambers consolidate. These possibilities are considered in the following paragraphs.

Lonsdale (1977a) compared the detailed geomorphology of the East Pacific Rise at $3^{\circ} 25^{\prime} \mathrm{S}$ with the Kilauea east rift, proposing that lateral injection of dikes occurs along the axis of the rise, as it does at Kilauea (Murata and Richter, 1966; Fiske and Jackson, 1972). The Kilauea analogy is instructive petrologically as well. Wright and Fiske (1971) documented in detail the fractionation and mixing of historic primitive olivine tholeiite summit magmas with evolved, iron-enriched basalts in the dike injection zone of the rift. The critical feature of the fractionation seems to be that along the rift, magmas are removed and isolated from the main cauldron beneath the Kilauea summit. Replenishment in the summit cauldron is too frequent and complete for magmas ever to evolve much from primitive compositions. But along the rift, magmas can sit in relative isolation for years or decades. The small size of the magma bodies and proximity to the 
surface allow them to lose considerable heat; hence, they fractionate greatly. On the East Pacific Rise or Galapagos Rift, this would equally readily allow the liquidus temperatures of injected basalts to drop by the approximately $100^{\circ}$ necessary to produce residual ferrobasalts crystallizing only clinopyroxene and plagioclase (e.g., Scheidegger, 1973; Bender et al., 1978; Fujii et al., 1978). These types of temperature drops seem unlikely in large, recurrently replenished magma chambers of sizes comparable to those of the East Pacific Rise (Usselman and Hodge, 1978).

The Kilauea analogy also is mechanically apt, in that it provides a ready mechanism to constrain dike injection to within a very narrow zone (Fiske and Jackson, 1972). The stress regime along an axial "shield volcano" should be very similar to that which controls lateral dike injection at Kilauea and keeps it within the rift zone, eruption after eruption. This analogy may not be appropriate in every respect for the East Pacific Rise or the Galapagos Rift, but it certainly seems relevant to a number of suggestions that magma moves along the length of rise or ridge magma chambers (e.g., the Reykjanes Ridge; Schilling, 1973; the East Pacific Rise, Lonsdale, 1977a; the Galapagos Rift, Crane, 1979; Sinton and Hey, 1979). More probably, magma injection along one portion of the base of the magma chamber triggers an eruption nearby where the crustal lid is thinnest. As lavas pile up, the locus of eruption shifts away from this point, always to the place of least superincumbent load. The mechanism would be similar to that proposed by Simkin (1972) for successive eruptions above radial dikes of Galapagos Island volcanoes, except that injection is linear, not radial. Walker (1975) has proposed a similar eruption mechanism for Icelandic fissure eruptions. Magmas left fractionating in the rift zone from previous injection events could be pushed out ahead of newer magmas, as they are on Kilauea, and partially hybridize with them. The magmas newly injected into the crust would on average have the bulk composition of the magma chamber unless the volume of primitive injected magma is unusually large. Based on the compositions of East Pacific Rise basalts, and the limitations imposed by Figure 7, this average bulk composition for the East Pacific Rise at $9^{\circ} \mathrm{N}$ is probably a moderately fractionated olivine tholeiite with less than 100 parts per million $\mathrm{Ni}$, about 8 per cent $\mathrm{FeO}^{*}$, and 9 per cent $\mathrm{MgO}$.

The structure and stratigraphy of the cumulate and massive gabbro portions of opiolites is independent evidence that the bulk composition of magma chambers beneath spreading centers rarely evolve to ferrobasalt compositions. In addition, ophiolites provide another mechanism for isolating pockets of fractionating magmas which could be tapped to form secondary volcanic peaks on axial shield volcanoes or plateaus. Magma chambers which reach a near steady-state bulk composition for any length of time should have little cryptic variation (variation in mineral compositions) through most of their cumulate sections. This situation has been succinctly described for the Semail ophiolite by Hopson et al. (1977, p. 1025) as follows:
"The sequence records gravitational differentiation during spreading away from a central feeding system. The basal dunite is a local massive accumulation of 01 + Chr + xenolithic harzburgite deposited almost above feeder. The lower layered zone accumulated farther out but where repeated influx of primitive magma still caused recurrent sedimentation of olivine. The higher layered zone accumulated upward and progressively farther from the feeder; however, the lack of strong progressive cryptic variation (emphasis mine) suggests a continual replenishment of the fractionating melt by new magma. The upper zone crystallized from unreplenished residual melt no longer in contact with the feeder system. Here extreme fractionation locally produced residual plagiogranite."

This type of stratigraphy, especially the development in upper gabbros of quartz diorites ("plagiogranites"), is a common feature of the several ophiolites described by Coleman (1977). Evolved melt pockets, which could eventually crystallize to quartz-diorite compositions, should reside in the upper reaches of the cumulate portions of the crust at the margins of the East Pacific Rise axial plateau or shield volcano. Their isolation from the main locus of fissure eruption would ensure against mixing with olivine tholeiite. Deep faulting at the margins of the plateau could well tap them. Secondary peaks at the plateau margins therefore may have the most fractionated compositions on the East Pacific Rise.

Isolation of ferrobasalt melts in shallow pockets in the crust is an intrinsic feature of the propagating rift model of Sinton and Hey (1979), which was constructed especially with the Galapagos Rift in mind. It also follows neatly from the tectonic model of the Galapagos Rift of van Andel and Ballard (1979) in which the zones of most rapid extension shift back and forth around newly formed volcanic ridges. On the East Pacific Rise axial plateau, where the fissure zone is quite wide and about $1.5 \mathrm{~km}$ east of the center of the plateau, it is likely that here, too, the fissure zone shifts back and forth, leaving previously injected melts to fractionate in intrusions zones which are, for the time being, cut off from the main supply of magmas.

A most interesting question is why ferrobasalts occur on some intermediate and fast-spreading ridges but not others. The Costa Rica Rift, for example, spreads at a rate virtually identical to that of the Galapagos Rift, from which it is offset by a pair of closely spaced fracture zones (Lonsdale and Klitgord, 1978), but it lacks ferrobasalts, and the high-amplitude magnetic anomalies thought to be associated with abundant ferrobasalts in the crust (Anderson et al., 1975). The crest of the East Pacific Rise at $21^{\circ} \mathrm{N}$, where the spreading rate is comparable to that of the Galapagos and Costa Rica Rifts, has been extensively sampled by submersible, yet all the basalts are olivine tholeiites (RISE Project Group, 1980; Hawkins and Melchior, 1980). These examples are another indication that ferrobasalts do not usually evolve in large axial magma chambers. Sinton and Hey (1979) would relate the occurrence of ferrobasalts strictly to the tectonic regime of propagating rifts. Yet this can hardly apply to the East Pacific Rise at $9^{\circ} \mathrm{N}, 3^{\circ} 25^{\prime} \mathrm{S}$, 
and $13^{\circ} 13^{\prime} \mathrm{S}$-all places where ferrobasalts have been recovered and where there is no indication of propagating rifts. Ferrobasalts have also been recovered on considerably older sections of East Pacific Rise crust during Legs 16 and 34 (Fig. 2), which implies continuity of ferrobasalt production rather than an origin requiring specialized tectonic circumstances. Hekinian and Morel (this volume) find a significant correlation between spreading rate and the occurrence of ferrobasalt, although there are exceptions such as those just cited.

I suggest that the determining factor is the shape and depth of the magma chamber. Where it is shallow, and has a broad flat top, the zone of magma injection will be broad, and able to shift from place to place in the manner suggested for the Galapagos Rift by van Andel and Ballard (1979). This will promote isolation of magma pockets, thence derivation of ferrobasalts. Where its average depth is larger, and it has a more truly triangular or tapered cross section, magmas will repeatedly emerge only from a very narrow zone, dike often splitting dike. They would have virtually no residence time in the dike injection zone, hence could not fractionate to ferrobasalt compositions. This might also be the explanation for the rarity of ferrobasalt compositions in the pillowed and sheeted-dike portions of ophiolites such as Troodos, where a magma chamber evidently existed (Cann, 1974; Allen, 1975) but where the frequency of dike-on-dike injection indicates an intrusion zone less than 50 meters wide (Kidd, 1977). A deep-tow survey (Normark, 1976), seismic studies (Reid et al., 1977), and submersible observations (CYAMEX, 1979; Rise Project Group, 1980) all indicate a narrow magma chamber, and a very narrow intrusion zone at the East Pacific Rise crest at $21^{\circ} \mathrm{N}$. There, hydrothermal vents, where waters as hot as $380^{\circ} \mathrm{C}$ are emerging, are clustered near a central volcanic ridge about 75 meters wide which is the locus of fissure eruptions. This occurs in a faulted zone some 1-2 km wide at the crest of a considerably less prominent axial block than at $9^{\circ} \mathrm{N}$. No geological evidence is given in these reports for any off-axis secondary volcanism.

The shape of the magma chamber probably becomes broad and flat where magma supplies are high relative to spreading rate. The extreme example of this, of course, is the Reykjanes Ridge and Iceland, where ferrobasalts are abundant (e.g., Schilling, 1973; Wood, 1978), even though spreading rates along that portion of the Mid-Atlantic Ridge are very low. In a less spectacular way, this might also explain petrologic variations along the Galapagos Rift, and contrasts between it and the Costa Rica Rift. Schilling et al. (1976) found a remarkable enrichment in iron in basalts dredged from the Galapagos Rift between $85^{\circ}$ and $86^{\circ} \mathrm{W}$, the same general longitude of Sites 424 and 425 drilled during Leg 54 . Basalts both to the west of this region on the Galapagos Rift, and to the east on the Costa Rica Rift, are significantly less iron-enriched.

Crane (1979) argued on geomorphologic grounds that magma pulses move eastward along the Galapagos Rift from the vicinity of the Galapagos Islands. Sinton and Hey (1979) linked the occurrence of ferrobasalts near the eastern end of the Galapagos Rift to an eastward propagating rift, essentially the tectonic regime proposed by Crane. Anderson et al. (1975) ascribed high-amplitude magnetic anomalies found both west and east of the Galapagos Islands to a high proportion of highly magnetized ferrobasalt pillows in the crust. On this basis, ferrobasalt was inferred to be much less abundant on the Costa Rica Rift, where high-amplitude magnetic anomalies do not occur. Sinton and Hey (1979) place the eastern and western boundaries of the high-amplitude belt of magnetic anomalies at the present limits of their propagating rift.

The underlying cause of these ferrobasalt distributions and high-amplitude magnetic anomalies is, in the view of most of the workers, the Galapagos Island hot spot or melting anomaly, which lies athwart the Galapagos Rift near $91^{\circ} \mathrm{W}$, toward which point the Rift shoals considerably. Crane (1979) would have magmas piped all the way down the rift from the vicinity of the Galapagos Islands. This is unlikely, however, in view of the depleted compositions of basalts dredged and drilled near $86^{\circ} \mathrm{W}$ compared with those dredged closer to the islands (Schilling et al., 1976).

I would like to propose a simple alternative that has only circumstantial evidence and perhaps some plausibility to support it. Consider the effect of tilting, even very slightly, a shallow, interconnected axial magma chamber, by heating and expanding a wide zone of mantle beneath and around the Galapagos Islands. The segment of the Galapagos Rift near $86^{\circ} \mathrm{W}$ drops in elevation some 213 meters in 74 km (Allmendinger and Riis, 1979), a part of the general decrease in elevation from the Galapagos Islands. Magmas within the magma chamber would tend to move eastward down the rift under the combined impetus of hydraulic pressure and gravity. Near the eastern terminus of the Galapagos Rift at the Ecuador fracture zone, I suggest that the magma chamber would be inflated, its top becoming flatter and less tapered. This would enhance the potential to form isolated, small magma bodies, and hence lead to eruption of more ferrobasalts. The distances magmas would move along the rift need at most be tens of kilometers to produce this effect. This is no more than the length of the Kilauea east rift, where a similar gravitational mechanism evidently operates (Fiske and Jackson, 1972). Over such limited distances, one would not expect undepleted magmas supplied near the Galapagos Islands to be channeled. No tilting affects the Costa Rica Rift, offset as it is by fracture zones, and hence no ferrobasalts occur there.

The tilting of the Rift near $86^{\circ} \mathrm{W}$ has occurred only recently, since Site 425 , on crust $1.2 \mathrm{~m} . y$. old and $62 \mathrm{~km}$ to the north of the Rift, is outside the belt of high-amplitude magnetic anomalies. Its basalts are less evolved overall than those presently erupting on the rift. Tilting has apparently progressed eastward, based on the eastward narrowing of the belt of high-amplitude magnetic anomalies (Sinton and Hey, 1979).

Since all the basalts sampled by submersible from the Galapagos Rift have the $\mathrm{TiO}_{2}$ and $\mathrm{FeO}^{*}$ of ferrobasalts, as previously discussed, it is possible that the bulk com- 
position of magmas within the Galapagos Rift magma chamber at $86^{\circ} \mathrm{W}$ became more iron-enriched as the tilting occurred. Schilling et al. (1976) and Corliss et al. (1979) suggest that this may be because of unusually efficient hydrothermal cooling along this portion of the Rift. This is not necessary because, in response to tilting, the top of the magma chamber would try to seek a common level. Hence magma migration would be mainly at the top of this chamber, and into the crust above it, where thermal gradients are greatest. Magmas will correspondingly fractionate as they lose heat moving laterally into progressively colder rocks. If primitive, uniform magmas are supplied at a uniform rate all along the base of the rift, then this process by itself will ensure that the average composition of lavas will be more fractionated at the eastern end of the rift. More probably, the rate of magma supply from the mantle is less with increasing distance from the Galapagos Island hot spot. The relative undersupply at the eastern end of the rift is counterbalanced by shifting of fractionated magmas near the top of the magma chamber gravitationally eastward along the rift. Under such circumstances, the size of the magma reservoir at the eastern end of the rift could actually be less than to the west. Its shape, and the bulk compositions of magmas within it, are different.

This example has been stressed to illustrate that under appropriate, albeit hypothetical, circumstances, quite different ranges of basalt compositions should erupt along different segments of the same rise or rift, as well as along different rises with similar geomorphologies and spreading rate. Bulk magma chamber compositions may become quite fractionated. The only correct way to judge this, however, is to determine the range of compositions erupted from the particular rise segment. By and large, depending on factors such as the shape and depth of magma chambers, a range in compositions should exist, because there is no way to prevent formation of all shallow fractionating magma pockets. There are consequently no particular tectonic regimes with which ferrobasalts should be uniquely associated. Considering the various rise and rift segments discussed here, the general association of ferrobasalts with fastspreading rises is still valid. However, special tectonic regimes such as propagating rifts may be necessary for them to be abundant along spreading segments separating at intermediate rates such as the Galapagos Rift and the Juan de Fuca Ridge.

\section{FERROBASALTS ALONG RIFTED SEGMENTS OF THE MID-ATLANTIC RIDGE}

It is ironical that mixing between primitive olivine tholeiites and ferrobasalts evidently occurs on the MidAtlantic Ridge (Figure 7), where ferrobasalts are rare, when it does not occur on the East Pacific Rise and Galapagos Rifts, where they are abundant. It is important to decide how and where such mixing occurs on the Mid-Atlantic Ridge, and whether or not shallow axial magma chambers were involved.

The existence of Mid-Atlantic Ridge magma chambers has been a matter of some controversy. The Mid-
Atlantic Ridge has a much slower spreading rate (1-2 $\mathrm{cm} / \mathrm{y}$. half rate) than either the East Pacific Rise or the Galapagos Rift; and for most of its length, it has a pronounced axial rift rather than a plateau or "shield volcano". Exceptions are those portions thought to be near hot spots or plumes in the mantle which give rise to features such as Iceland and the Reykjanes Ridge. These will not be considered here.

Geophysical studies have failed to turn up evidence on the Mid-Atlantic Ridge for large, axial magma chambers (see summaries in Rosendahl, 1976; Nisbet and Fowler, 1978, and Sleep and Rosendahl, 1979). Although many landforms within the rift valley, including a central fissured zone, resemble those on faster spreading rises, the occurrence of 200-to 300-meter high volcanic peaks ("central highs") $2-5 \mathrm{~km}$ long spaced between fracture zones averaging only about $30 \mathrm{~km}$ apart led Lonsdale (1977a, p. 343) to conclude that "segments of slow-spreading ridge crests have much smaller, unconnected magma chambers which are impermanent at any one site on the axis." Allmendinger and Riis (1979) argued that although the general trend of the Mid-Atlantic Ridge in the FAMOUS region must overlie a magma source with the same general trend, magmas are not supplied to all points of the ridge along this trend. In consequence, the Ridge becomes broken up into short rift segments where magmas are supplied, and closely spaced transform faults which are structural depressions where magmas are not supplied. Also, the rift segments do not parallel the general trend of the ridge nor are they orthogonal to fracture zones. The underlying cause of all of this, they believe, is that magma sources are deep, a conclusion independently reached by Sleep and Rosendahl (1979) from numerical models of the thermal and physical structure of slow-spreading ridges.

Hekinian et al. (1976), Bryan and Moore (1977), and Bryan et al., (1979) have argued strenuously on petrologic grounds that a shallow axial magma chamber spans the width of the FAMOUS rift at $37^{\circ} \mathrm{N}$ despite lack of geophysical evidence for this specific portion of the rift (Fowler, 1976). They were impressed with a striking chemical zonation of lavas about the center of the rift, which they believed could be explained by the near-simultaneous tapping of a zoned magma chamber at a number of places across the width of the rift. Flower and Robinson (1979) re-interpreted the data of Bryan and Moore (1977) in the light of geophysical evidence and comparisons with nearby Site 332. They favor a narrow eruptive zone in the center of the rift (as also argued by Nisbet and Fowler, 1978), and view the zonation as a consequence of progressive burial of lavas spreading away from the central eruptive fissure zone.

Several aspects of Mid-Atlantic Ridge magma reservoir and conduit systems were deduced by Natland (1978a) on the basis of lava stratigraphy at Sites 332 and 395 , and the crystallization history of basalts at Site 395 Natland, 1978b). At both sites, at least two separate reservoir-conduit systems tapped different magma sources, possibly at different depths in the mantle, and supplied them to the floor of the axial rift either simultaneously or in sequence. The example which best illustrates how 
ferrobasalts evolve on the Mid-Atlantic Ridge is Site 395 , as will now be discussed.

Two types of hybridization are manifest in the lavas of Site 395, which was drilled into Miocene crust at $23^{\circ} \mathrm{N}$ on the Mid-Atlantic Ridge. The first is evident on Figure 7. Averages of multiple analyses of three distinct aphyric basalt types (which also fall in Field A on Fig. 6) fall close to the mixing line between representative primitive olivine tholeiites and ferrobasalts proposed by Rhodes and Dungan (1979). Yet each of these three aphyric basalt types has an internal chemical variation (so-called flat- $\mathrm{TiO}_{2}$ trends) which Kirkpatrick (1978) modeled as a consequence of simultaneous plagioclase resorption and olivine fractionation. This was caused by passage of the melt from regions where both phases were crystallizing simultaneously, to shallower depths where only olivine crystallized. Petrographic evidence for this is the occurrence of rare, resorbed plagioclase phenocrysts in the basalts (Natland, 1978a).

Evidently, then, mixing occurred prior to ascent in magma reservoirs sufficiently deep for the effects of a drop in pressure to be manifested petrologically. This would probably have been at least in the deep crust, perhaps in the upper mantle itself.

The other type of mixing occurred in strongly porphyritic basalts, rich in plagioclase and lesser olivine and clinopyroxene phenocrysts. Dungan and Rhodes (1978) inferred that mixing had occurred in these basalts on the basis of disequilibrium between host glass compositions and the cores of strongly zoned plagioclase and olivine phenocrysts, and on the basis of glass inclusions in the phenocrysts far more primitive than host glass compositions. Natland (1978b) argued that these glass inclusions were trapped during growth of skeletal projections from the phenocrysts before they were strongly zoned during the mixing event. These were inferred to be evidence that the crystals experienced sharp increases in cooling rate, probably during transfer in narrow conduits between larger magma bodies at shallow, fairly cold levels in the crust. These crystals and their associated primitive liquids were injected into surprisingly evolved magmas. Some were quartz-normative and iron-enriched, as evidenced by the field labeled " $P$ ", on Figure 6, which encloses averages of glasses from the chilled margins of porphyritic basalt types, from Melson (1978). Natland (Crystal Morphologies chapter, this volume) noted the general similarity of groundmass mineralogies and textures in these basalts to those of East Pacific Rise ferrobasalts.

Here, then, is evidence for another type of mixing, between primitive and evolved porphyritic magmas at shallow levels in the crust. The bulk compositions of these porphyritic basalts appear little evolved, because they are so charged with olivine and plagioclase phenocrysts that crystallized in a primitive magma. Mixing then occurs at all levels in the crust beneath the rift valley of the Mid-Atlantic Ridge. At Site 395, mixing was between ferrobasalts and large percentages (perhaps 50$70 \%$ ) of truly primitive olivine tholeiite.

One can make the argument that all the basalt types at Site $\mathbf{3 9 5}$ are fundamentally primitive compositions. If it had not been for what might be considered chance encounters with pockets of evolved melt, they would have erupted in a primitive state. Only mixing has given them something akin to intermediate olivine tholeiite compositions. Mixing at deep levels in the crust may have been in an episodically replenished magma chamber, since the aphyric basalt types are very similar chemically. However, between each episode of mixing, the magma chamber would have crystallized up to 80 per cent of its volume and been diminished in size by the same amount. At each inflation, it might have been restored to its original volume. Since the various aphyric lavas erupted through a long interval of time encompassing two magnetic reversals $(10,000$ to $100,000 \mathrm{y}$; Johnson, 1978), the extent of fractionation is not surprising. In contrast to magma chambers beneath fast-spreading rises, a large cryptic variation in cumulus mineral chemistries is implied. It also seems that the interval between mixing and eruption on the rift valley floor was typically short, since little fractionation occurred after mixing. Intervals between mixing events, however, were long, as evidenced by the magnetic reversals, allowing extreme residual iron-enriched magmas to evolve. The lack of abundant Mid-Atlantic Ridge ferrobasalts is because the mechanics of magma ascent are rapid, allowing on average only small degrees of fractionation following mixing. Ferrobasalts do evolve, but only in residual pockets which are later entrained in, and therefore diluted by, ascending primitive magmas; they rarely get to the sea floor on their own.

The interbedding at Site 395 of aphyric and highly porphyritic basalts which have fundamentally different chemistries and mixing histories is the strongest evidence that separate magma reservoir and conduit systems supplied lavas side by side on the Mid-Atlantic Ridge $7 \mathrm{~m}$.y. ago. One group of primitive magmas intercepted and mixed with ferrobasalt compositions deep in the crust, but not thereafter; one intercepted and mixed with ferrobasalt compositions at shallow levels in the crust, but not before. In the first group, phenocrysts either did not grow, or were subtracted from the melt; in the other, they both grew and were concentrated to such an extent that bulk lava compositions depart significantly from liquid compositions. Natland (1978b) and Propach et al., (1978) argued that accumulation of phenocrysts and glomerocrysts in small magma bodies occurred by sinking. Flowage differentiation may also have occurred. The two separate, unlinked systems produced magmas which never mixed together, although mixing occurred within each. This can only mean that the dimensions of the reservoir-conduit systems were small (as implied by the model of Sleep and Rosendahl, 1979), and that there could not have been a large, shallow axial magma chamber on this part of the Mid-Atlantic Ridge at that time.

These petrologic inferences seem to be in full agreement with geophysical models of the current axis of the Mid-Atlantic Ridge. Similar arguments have been made for Site 332 in the FAMOUS area based on other geochemical criteria (e.g., Blanchard et al., 1976; Natland, 1978a). Geochemical arguments have also been put for- 
ward to show that FAMOUS rift basalts are not related by crystal accumulation or fractionation in a rift-wide magma chamber (Langmuir et al., 1977) despite the contentions of Bryan and coworkers. Perhaps the style of Mid-Atlantic Ridge eruption is more evident in deeppenetration DSDP sites where downhole chemical and magnetic stratigraphy can be well established than it is from submersible samples from the median rift. No matter how precisely known the location of submersible samples, the sequence of eruption cannot be as well established. I favor the conclusion based on DSDP data that magma chambers are an ephemeral, discontinuous feature beneath spreading segments of the Mid-Atlantic Ridge axial rift, and occur as small bodies at deep, rather than shallow, levels in the crust.

\section{CONCLUSION}

No study which draws as heavily as this one on so many aspects of marine geophysical and petrological research, and which deals with so many localities, can hope to establish comprehensive proof. Outlining the contrasting economy of ferrobasalts in rise, rift, and ridge magmatism seemed a useful way to approach the petrologic problems of formation of oceanic crust, particularly the question of axial magma chambers. Certain features of axial magmatism now seem evident. There is, for example, nearly as much petrologic variability among rise and ridge crests as there are well-studied examples of each. The variability is not so much in the rock types-abyssal tholeiites of one sort or another are nearly universal-but in the contrasting degrees to which different magmatic processes influence rock compositions. We see, for example, fundamental differences in the degree of melting, producing basalts at the East Pacific Rise and the Galapagos Rift. We see ferrobasalts abundant on some intermediate-spreading rises but not others. Contrasting patterns of mixing characterize the East Pacific Rise and the Mid-Atlantic Ridge. Some spreading centers have large, shallow magma chambers, others do not. This is not strictly a function of spreading rate, as even slow-spreading ridges can have positive axial relief and large, shallow magma chambers if they are near a melting anomaly such as Iceland or the Galapagos Islands. The petrologic problems are inextricably bound up with the problems of crestal geomorphology, the spacing of fracture zones, and spreading rates. Compositional source heterogeneities with or without associated hot spots may be superposed on all of these.

The existence of shallow axial magma chambers, upon which much petrologic inference stated herein depends, is based entirely on the results of explosion and earthquake seismology, which have certain intrinsic limitations. We have only the crudest notion of the structure of axial magma reservoirs based on such data, and even this is subject to a certain amount of technical dispute (e.g., Bibee, 1979). Detailed, near-bottom observations are an important complement to such studies, since they have revealed many microtopographic features one might hope to find above magma chambers. Many of the conjectures made in this chapter, though, are based on subaerial analogies and are as yet unsup- orted by evidence from the sea floor. We are approaching a point, however, where a sufficient variety of rise and ridge segments are known well enough to contemplate and perform experiments as spreading occurs, at the volcanic stage. The next generation of rise and ridge investigations could well monitor inflation of magma chambers and magma movements prior to and during eruptions, finally establishing a firm basis for the mechanics of axial magmatism.

\section{ACKNOWLEDGMENTS}

This paper is far more the result of a collective effort than an individual enterprise. I would especially like to thank J. R. Cann, D. A. Clague, R. James Kirkpatrick, and B. R. Rosendahl for reviews of the manuscript and many a lively conversation on these subjects in years past. I would also like to acknowledge the importance of discussions with two Leg 54 shipboard colleagues, Roger Hekinian and Ramesh Srivastava, concerning contrasts between Mid-Atlantic Ridge and East Pacific Rise volcanism. Finally, to the seminal contributions of Mike Rhodes, a shipboard colleague during Leg 45 , I owe the kernel of the arguments pertaining to magma mixing. Despite terming this work a collective effort, I assume full responsibility for converting it all into print.

\section{REFERENCES}

Allen, C. R., 1975. The petrology of a portion of the Troodos plutonic complex, Cyprus [unpublished Ph.D. thesis]. University of Cambridge.

Allmendinger, R. W., and Riis, F., 1979. The Galapagos Rift at $86^{\circ} \mathrm{W}, 1$, regional morphological and structural analysis, J. Geophys. Res., v. 84, p. 5379-5389.

Anderson, R. N., Clague, D. A., Klitgord, K. D., Marshall, M., and Nishimori, R., 1975. Magnetic and petrologic variations along the Galapagos Spreading Center and their relation to the Galapagos melting anomaly, Geol. Soc. Amer. Bull., v. 86, p. 683-694.

Ballard, R. D., Holcomb, R. T., and van Andel, Tj. H., 1979. The Galapagos Rift at $86^{\circ} \mathrm{W}, 3$, sheet flows, collapse pit and lava lakes of the rift valley, J. Geophys. Res., v. 84, p. $5407-5422$.

Bass, M. N., 1971. Variable abyssal basalt populations and their relation to sea-floor spreading rates, Earth Planet. Sci. Lett., v. 11, p. 18-22.

Batiza, R., Rosendahl, B. R., and Fisher, R. L., 1977. Evolution of oceanic crust, 3 , petrology and chemistry of basalts from the East Pacific Rise and the Siqueiros transform fault, J. Geophys. Res., v. 82, p. 265-276.

Bender, J. F., Hodges, F. N., and Bence, A. E., 1978. Petrogenesis of basalts from the Project FAMOUS area: experimental study from 0 to 15 kbars, Earth Planet. Sci. Lett., v. 41, p. 277-302.

Bibee, L. D., 1979. Crustal structure in areas of active crustal accretion [unpublished thesis]. University of California, San Diego.

Blanchard, D. P., Rhodes, J. M., Dungan, M. A., Rodgers, K. V., Donaldson, C. H., Brannon, J. C., Jacobs, J. W., and Gibson, E. W., 1976. The chemistry and petrology of basalts from Leg 37 of the Deep-Sea Drilling Project, $J$. Geophys. Res., v. 81, p. 4231-4246.

Bowen, N. L., and Schairer, J. F., 1935. The system MgO$\mathrm{FeO}-\mathrm{SiO}_{2}, A m$. J. Sci., v. 26, p. 151-217.

Bryan, W. B., 1979. Regional variation and petrogenesis of basalt glasses from the FAMOUS area, Mid-Atlantic Ridge, J. Petrol., v. 20, p. 293-325. 
Bryan, W. B., and Moore, J. G., 1977. Compositional variations of young basalts in the Mid-Atlantic Ridge rift valley near lat $36^{\circ} 49^{\prime}$ N, Geol. Soc. Am. Bull., v. 88, p. 556-570.

Bryan, W. B., Thompson, G., and Michael, P. J., 1979. Compositional variation in a steady-state zoned magma chamber: Mid-Atlantic Ridge at $36^{\circ} 50^{\prime} \mathrm{N}$, Tectonophysics, v. 55, p. 63-85.

Cann, J. R., 1974. A model for oceanic crustal structure developed, Geophys. J. Roy. Astron. Soc., v. 339, p. 169187.

in press. The ocean crust. In Maxwell, A. E. (Ed.), The Sea (Vol. 7): New York (Wiley).

Clague, D. A., and Bunch, T. E., 1976. Formation of ferrobasalt at east Pacific midocean spreading centers, $J$. Geophys. Res., v. 81, p. 4247-4256.

Coleman, R. G., 1977. Ophiolites: New York (Springer-Verlag).

Corliss, J., Gordon, L. I., and Edmond, J. M., 1979. Some implications of heat/mass ratios in Galapagos Rift hydrothermal fluids for models of sea water-rock interaction and the formation of oceanic crust. In Talwani, M., Harrison, C., and Hayes, D. E., (Eds.), Deep Drilling Results in the Atlantic Ocean: Ocean Crust, Maurice Ewing Series 2: Washington (American Geophysical Union), p. 383-390.

Crane, K, 1978. Structure and tectonics of the Galapagos inner rift $86^{\circ} 10^{\prime} \mathrm{W}, J$. Geol., v. 86, p. $715-730$.

,1979. The Galapagos Rift at $86^{\circ} \mathrm{W}$ : morphological wave forms; evidence for a propagating rift, J. Geophys. Res., v. 84, p. 6011-6018.

CYAMEX Science Team, 1979. Massive deep-sea sulfide ore deposits recovered on the East Pacific Rise, Nature, v. 277, p. 523-528.

Dungan, M. A., and Rhodes, J. M., 1978. Residual glasses and melt inclusions in basalts from DSDP Legs 45 and 46: evidence for magma mixing, Contrib. Mineral. Petrol., v. 67 , p. 417-431.

Engel, A. E. J., Engel, C. G., and Havens, R. G., 1965. Chemical characteristics of oceanic basalts and the upper mantle, Geol. Soc. Am. Bull., v. 76, p. 719-734.

Fenner, C. N., 1929. The crystallization of basalts, Am. J. Sci., v. 18 , p. $225-253$.

Fiske, R. D., and Jackson, E. D., 1972. Orientation and growth of Hawaiian volcanic rifts: the effect of regional structure and gravitational stresses, Royal Soc. (London) Proc., A, v. 329 , p. 299-326.

Flower, M., and Robinson, P. T., 1979. Evolution of the FAMOUS ocean ridge segment: evidence from submarine and Deep-Sea Drilling Investigations. In Talwani, M., Harrison, C. G., and Hayes, D. E. (Eds.), Deep Drilling Result in the Atlantic Ocean: Ocean Crust, Maurice Ewing Series 2: Washington (American Geophysical Union), p. 314330.

Fowler, C. M. R., 1976. Crustal structure of the Mid-Atlantic Ridgecrest at $37^{\circ} \mathrm{N}$, Geophys. J. Roy. Astron. Soc., v. 47 , p. $459-591$.

Frey, F. A., Bryan, W. B., and Thompson, G., 1974. Atlantic Ocean floor: geochemistry and petrology of basalts from Legs 2 and 3 of the Deep Sea Drilling Project, $J$. Geophys. Res., v. 79, p. 5507-5527.

Fujii, T., Kushiro, I., and Hamuro, K., 1978. Melting relalations and viscosity of an abyssal olivine tholeiite. In Melson, W. G., Rabinowitz, P. D., et al., Initial Reports of the Deep Sea Drilling Project, 45: Washington (U.S. Govt. Printing Office), p. 513-516.

Hawkins, J. W., and Melchior, J., 1980. Descriptive cata$\log$ of basalt samples from the East Pacific Rise at $21^{\circ} \mathrm{N}$, Scripps Institution of Oceanography Reference, v. 80 , p. 4.
Hekinian, R., Moore, J. G., and Bryan, W. B., 1976. Volcanic rocks and processes of the Mid-Atlantic Ridge rift valley near $36^{\circ} 49^{\prime}$ N, Contrib. Mineral. Petrol., v. 58, p. 83-110.

Hopson, C. A., Pallister, J. S., Coleman, R. G., and Bailey, E. B., 1977. Geological section of the Semail ophiolite near Ibra, southeastern Oman Mountains, Sultanate of Oman, Geol. Soc. Am. Abstr., v. 9, p. 1024-1025.

Irvine, T. N., 1979. Rocks whose composition is determined by crystal accumulation and sorting. In Yoder, H. S., Jr. (Ed.), The Evolution of the Igneous Rocks - Fiftieth Anniversary Perspectives: Princeton (Princeton University Press), p. 245-306.

Johnson, H. P., 1978. Paleomagnetism of igneous rock samples - DSDP Leg 45. In Melson. W. G., Rabinowitz, P. D., et al., Initial Reports of the Deep Sea Drilling Project, 45: Washington (U.S. Govt. Printing Office), p. 387-396.

Johnson, J., 1979. Transitional basalts and tholeiites from the East Pacific Rise, $9^{\circ} \mathrm{N}, J$. Geophys. Res., v. 84, p. $1635-1652$.

Kay, R., Hubbard, N., and Gast, P. W., 1970. Chemical characteristics of ocean ridge volcanic rocks, J. Geophys. Res., v. 75 , p. $1585-1613$.

Kidd, R. G. W., 1977. A model for the process of formation of the upper oceanic crust, Geophys. J. Roy. Astron. Soc., v. 50, p. $149-183$.

Kirkpatrick, R. J., 1978. Petrology of basalts: Hole 396B DSDP Leg 46. In Dmitriev, L., Heirtzler, J. R., et al., Initial Reports of the Deep Sea Drilling Project, 46: Washington (U.S. Govt. Printing Office), p. 165-178.

Klitgord, K. D., and Mudie, J. D., 1974. The Galapagos spreading centre: a near-bottom geophysical survey, Geophys. J. Roy. Astron. Soc., v. 38, p. 563-586.

Kuno, H., 1978. Differentiation of basalt magmas. In Hess, H. H., and Poldervaart, A. (Eds.), Basalts (Vol. 2): New York (Wiley), 623-688.

Langmuir, C. H., 1979. Chemical variations in magmas erupted from a periodically refilled magma chamber, EOS, v. 60 , p. 971.

Langmuir, C. H., Bender, J. F., Bence, A. E., Hanson, G. N., and Taylor, S. R., 1977. Petrogenesis of basalts from the FAMOUS area, Mid-Atlantic Ridge, Earth Planet. Sci. Lett., v. 36, p. 133-156.

Lonsdale, P., 1977a. Structural geomorphology of a fastspreading rise crest: the East Pacific Rise near $3^{\circ} 25^{\prime} \mathrm{S}$, Mar. Geophys. Res., v. 3, p. 251-293.

1977b. Abyssal pahoehoe with lava coils at the Galapagos Rift, Geology, v. 5, p. 147-152.

1977c. Regional shape and tectonics of the equatorial East Pacific Rise, Mar. Geophys. Res., v. 3, p. 295-315.

Lonsdale, P., and Klitgord, K. D., 1978. Structure and tectonic history of the eastern Panama Basin, Geol. Soc. Am. Bull., v. 89, p. 981-999.

Lonsdale, P., and Spiess, F. N., 1979. A pair of young cratered volcanoes on the East Pacific Rise, J. Geol., v. 87, p. 157-173.

Melson, W. G., 1978. Chemical stratigraphy of Leg 45 basalts: electron probe analyses of glasses. In Melson, W. G., Rabinowitz, P. D., et al., Initial Reports of the Deep Sea Drilling Project, 45: Washington (U.S. Govt. Printing Office), p. 507-511.

Melson, W. G., Vallier, T. L., Wright, T. L., Byerly, G. R., and Nelen, J. A., 1976. Chemical diversity of abyssal volcanic glass erupted along Pacific, Atlantic, and Indian Ocean sea-floor spreading centers, Geophys. Mon. 19: Washington (American Geophysical Union), p. 351-368. 
Murata, K. J., and Richter, D. H., 1966. Chemistry of the lavas of the 1959-60 eruption of Kilauea Volcano, Hawaii, U.S. Geol. Survey Prof. Paper 537-A.

Natland, J., 1978a. Comparison of the chemical and magnetic stratigraphy of DSDP Sites 332 and 395 . In Melson, W. G., Rabinowitz, P. D., et al., Initial Reports of the Deep Sea Drilling Project, 45: Washington (U.S. Govt. Printing Office), p. 657-677.

,1978b. Crystal morphologies in basalts from DSDP Site $395,23^{\circ} \mathrm{N}, 46^{\circ} \mathrm{W}$, Mid-Atlantic Ridge. In Melson, W. G., Rabinowitz, P. D., et al., Initial Reports of the Deep Sea Drilling Project, v. 45: Washington (U.S. Govt. Printing Office), p. 423-445.

Nisbet, E. G., and Fowler, C. M. R., 1978. The Mid-Atlantic Ridge at $37^{\circ}$ and $45^{\circ} \mathrm{N}$ : some geophysical and petrological constraints, Geophys. J. Roy Astron. Soc., v. 54, p. 631660.

Normark, W. R., 1976. Delineation of the main extrusion zone of the East Pacific Rise at lat $21^{\circ} \mathrm{N}$, Geology, v. 4, p. 681-685.

O'Hara, M. J., 1977. The geochemistry of lavas erupted from a magma chamber undergoing fractional crystallization with periodic addition and intermingling of more primitive magma, Nature, v. 266, p. 503-507.

Orcutt, J., Kennett, B., and Dorman, L., 1976. Structure of the East Pacific Rise from an ocean bottom seismometer survey, Geophys. J. Roy. Astr. Soc., v. 45, p. 305-320.

Orcutt, J., Kennett, B., Dorman, L., and Prothero, W., 1975. A low velocity zone underlying a fast-spreading rise crest, Ibid., v. 256, p. 475-476.

Osborne, E. F., 1959. Role of oxygen pressure in the crystallization and differentiation of basaltic magma, Am. J. Sci. v. 257 , p. $609-647$.

,1962. Reaction series for subalkaline igneous rocks based on different oxygen pressure conditions, Am. Mineral., v. 47, p. 211-226.

Presnall, D. C., 1969. The geometrical analysis of partial fusion, Am. J. Sci., v. 267, p. 1178-1194.

Presnall, D. C., Dixon, J. R., O'Donnell, T. H., and Dixon, S. A., 1979. Generation of mid-ocean ridge tholeiites, $J$. Petrol., v. 20, p. 3-35.

Propach, G., Lee, S., and Prosser, E., 1978. Textural and compositional variations in dolerite units from Hole 395A. In Melson, W. G., Rabinowitz, P. D., et al., Initial Reports of the Deep Sea Drilling Project, 45: Washington (U.S. Govt. Printing Office), p. 529-534.

Reid, I., Orcutt, J. A., and Prothero, W. A., 1977. Seismic evidence for a narrow zone of partial melting underlying the East Pacific Rise at $21^{\circ} \mathrm{N}$, Bull. Geol. Soc. Am., v. 88, p. 678-682.

Rhodes, J. M., Blanchard, D. P., Rodgers, K. V., Jacobs, J. W., and Brannon, J. C., 1977. Petrology and chemistry of basalts from the Nazca Plate, Part 2-Major and trace element chemistry. In Yeats, R. S., Hart, S. R., et al., Initial Reports of the Deep Sea Drilling Project, 34: Washington (U.S. Govt. Printing Office), p. 239-244.

Rhodes, J. M., and Dungan, M. A., 1979. The evolution of oceanfloor basaltic magmas. In Talwani, M., Harrison, C. G., and Hayes, D. E. (Eds.), Deep Drilling Results in the Atlantic Ocean: Ocean Crust, Maurice Ewing Series 2: Washington (American Geophysical Union), p. 262-272.
RISE Project Group, 1980. East Pacific Rise: hot springs and geophysical experiments, Science, v. 207, p. 1421-1432.

Rosendahl, B. R., 1976. Evolution of oceanic crust 2: constraints, implications and inferences, J. Geophys. Res. v. 81, p. 5305-5314.

Rosendahl, B. R., Raitt, R. W., Dorman, L. M., Bibee, L. D., Hussong, D. M., and Sutton, G. H., 1976. Evolution of oceanic crust 1: a physical model of the East Pacific Rise crest derived from seismic refraction data, Ibid., v. 81, p. 5294-5304.

Rosendahl, B. R., Russell, S. D., Dorman, L. M., Johnson, S., 1978. Seismic model of the Galapagos Rift at $86^{\circ} \mathrm{W}$ and comparison to EPR at $9^{\circ} \mathrm{N}, E O S$, v. 59, p. 1139.

Scheidegger, K. F., 1973. Temperatures and compositions of magmas ascending along midocean ridges, Ibid. v. 78, p. 3340-3355.

Schilling, J.-G., 1973. Iceland mantle plume: geochemical study of Reykjanes Ridge, Nature, v. 242, p. 565-575.

Schilling, J.-G., Anderson R. N., and Vogt, P., 1976. Rare earth, $\mathrm{Fe}$ and $\mathrm{Ti}$ variations along the Galapagos spreading centre, and their relationship to the Galapagos mantle plume, Ibid., v. 261, p. 108-113.

Simkin, T., 1972. Origin of some flat-topped volcanoes and guyots. In Shagam, K., et al (Eds.), Studies in Earth and Space Sciences: Geol. Soc. Am. Mem., v. 132, p. 183-193.

Sinton, J. M., and Hey, R., 1979. Oceanic ferrobasalts, offridge magmas, and propagating rifts along the Galapagos spreading center, EOS, v. 60 , p. 971.

Sleep, N. H., and Rosendahl, B. R., 1979. Topography and tectonics of mid-oceanic ridge axes, J. Geophys. Res., v. 84 , p. $6831-6839$.

Usselman, T. M., and Hodge, D. S., 1978. Thermal control of low-pressure fractionation processes, J. Volcan. Geotherm. Res., v. 4, p. 265-281.

van Andel, Tj. H., and Ballard, R. D., 1979. The Galapagos Rift at $86^{\circ} \mathrm{W}, 2$, volcanism, structure, and evolution of the rift valley, J. Geophys. Res., v. 84, 5390-5406.

Wager, L. R., and Brown, G. M., 1967. Layered Igneous Rocks: San Francisco (W. H. Freeman and Company).

Wager, L. R., and Deer, W. A., 1939. Geological investigations in East Greenland, Part III. The petrology of the Skaergaard Intrusion, Kangerdlugssuaq, East Greenland, Medd. om Grønland, v. 105, p. 1-352.

Walker, G. P. L., 1975. Intrusive sheet swarms and the identity of crustal layer 3 in Iceland, J. Geol. Soc. Lond., v. 131, p. 143-161.

Wood, D. A., 1978. Major and trace element variations in the Tertiary lavas of eastern Iceland and their significance with respect to the Iceland geochemical anomaly, J. Petrol., v. 19 , p. 393-436.

Wright, T. L., and Fiske, R. S., 1971. Origin of the differentiated and hybrid lavas of Kilauea volcano, Hawaii, Ibid., v. 12 , p. $1-65$.

Yeats, R. S., Forbes, W. C., Heath, G. R., and Scheidegger, K. F., 1973. Petrology and geochemistry of DSDP Leg 16 basalts, eastern equatorial Pacific. In van Andel, $\mathrm{Tj}$. $\mathrm{H}$., Heath, G. R., et al., Initial Reports of the Deep Sea Drilling Project, 16: Washington (U.S. Govt. Printing Office), p. $617-640$. 